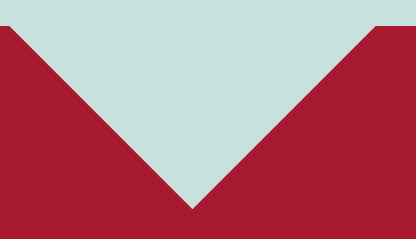

ALAN SHAPIRO

\title{
RE-FASHIONING
}

ANAKREON IN

\section{CLASSICAL ATHENS}


MORPHOMATA

LECTURES COLOGNE

2

HERAUSGEGEBEN VON GÜNTER BLAMBERGER UND DIETRICH BOSCHUNG

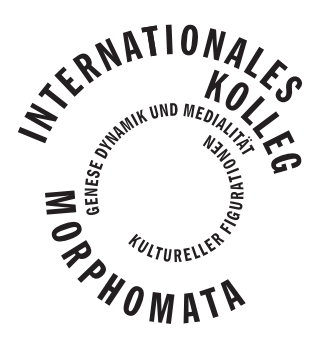




\section{RE-FASHIONING ANAKREON IN CLASSICAL ATHENS}


unter dem Förderkennzeichen 01UK0905. Die Verantwortung für den Inhalt der Veröffentlichung liegt bei den Autoren.

Bibliografische Informationen der Deutschen Nationalbibliothek: Die Deutsche Nationalbibliothek verzeichnet diese Publikation in der Deutschen Nationalbibliografie; detaillierte Daten sind im Internet über www.dnb.d-nb.de abrufbar.

Alle Rechte, auch die des auszugweisen Nachdrucks, der fotomechanischen Wiedergabe und der Übersetzung vorbehalten. Dies betrifft auch die Vervielfältigung und Übertragung einzelner Textabschnitte, Zeichnungen oder Bilder durch alle Verfahren wie Speicherung und Übertragung auf Papier, Transparente, Filme, Bänder, Platten und andere Medien, soweit es nicht $₫ 53$ und 54 UrhG ausdrücklich gestatten.

(C) 2012 Wilhelm Fink Verlag, München

Wilhelm Fink GmbH \& Co. Verlags-KG, Jühenplatz 1, D-33098 Paderborn Internet: www.fink.de

Lektorat: Krystyna Greub-Frącz / Frank Wascheck

Gestaltung: Miriam Röttgers / Kathrin Roussel

Satz: Kathrin Roussel

Printed in Germany

Herstellung: Ferdinand Schöningh GmbH \& Co. KG, Paderborn
This paper represents a revised and expanded version of a lecture that I gave in Cologne in April 2010, under the auspices of the Internationales Kolles Morphomata. I am grateful to the Directors of the Kolleg, Günter Blamberger and Dietrich Boschung, for the invitation to be among the first Morphomata Fellows and to present my research as part of a Ringvorlesung. I also thank Frank Wascheck and Thierry Greub for their help in preparing the manuscript for publication.-Earlier versions of the paper were delivered at the University of Sydney in 2008 and the University of Wisconsin at Madison in 2009. A brief version of the paper printed here was given at the American School of Classical Studies at Athens in June, 2011, as part of a conference in honor of Susan I. Rotroff. It is to her that I would like to offer this book, as a token of many years of friendship and inspiration. 
In my copy of "The Manner of Anacreon", Egoist Press, 1919, Hamilton Collier of Scarsdale, New York, has written on the flyleaf

My first real understanding of the Greeks.

I regret I am unable to agree with them.

from James Longenbach's poem "Exercise" (2009) 


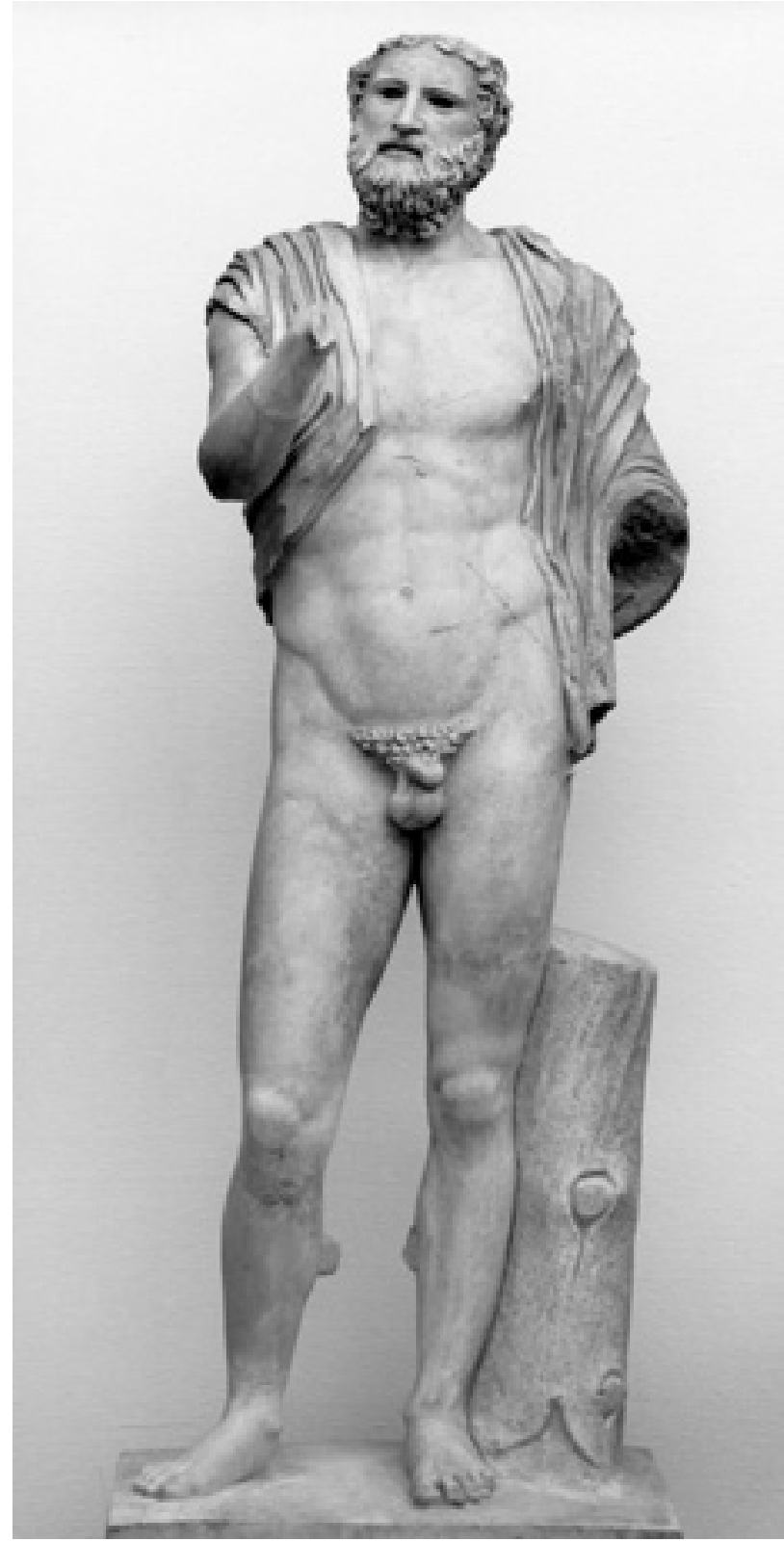

1 Copenhagen, Ny Carlsberg Glyptotek 491: Portrait Statue of Anakreon

\section{THE ANAKREON BORGHESE}

The portrait statue of the poet Anakreon, best known in a fine, full-length Roman copy today in Copenhagen (Figs. 1-5), ${ }^{1}$ represents a unique case in the history of Greek portraiture before the Hellenistic period. In contrast to the wretchedly meager state of our evidence for the portraits of most famous Greeks of the Archaic and Classical periods, for Anakreon we have a relative over-abundance of information. We know where the original statue stood, thanks to the traveler Pausanias, who saw and described it on the Athenian Akropolis $(1,25,1):^{2}$

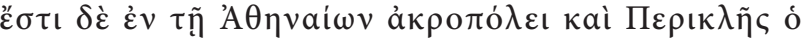

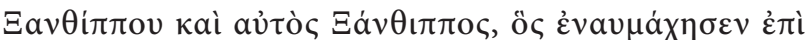

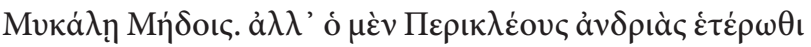

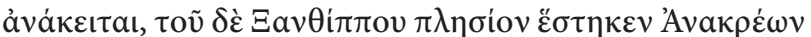

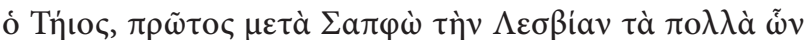

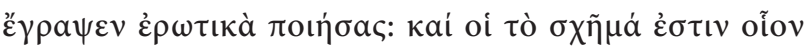

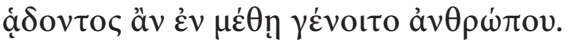

1 Copenhagen, Ny Carlsberg Glyptotek 491; Richter 1965, 76 no. 5 figs. 278. 279. 283; the first thorough publication by Poulsen 1931, 1-15. The statue was found in 1835 in a Roman villa outside Rome, at Monte Calvo, near Rieti. Before its acquisition by the Ny Carlsberg Glyptotek, it was in the Borghese Collection in Rome and, hence, is often referred to as the Anakreon Borghese. The Anakreon was found together with a second, well-known Roman copy of a portrait statue of a Greek poet, possibly Archilochos, now also in the Ny Carlsberg Glyptotek. See Moltesen 1987. The Copenhagen Anakreon has usually been dated to ca. $130-150$ C.E. See Klug 1995.

2 Judging by the context in Pausanias, the statue must have stood at the East end of the Parthenon. See Krumeich 1997, $69 \mathrm{f}$ 

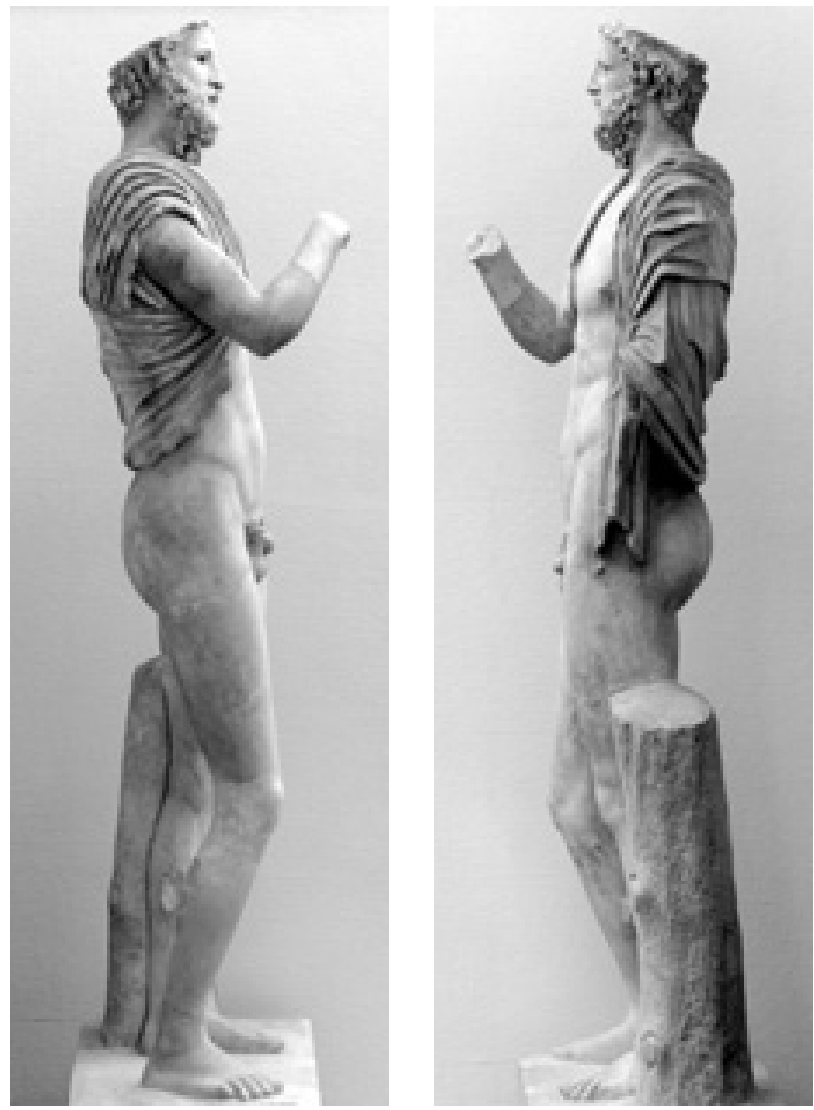

2 As Fig. 1: Right side view
3 As Fig. 1: Left side view

On the Athenian Acropolis is a statue of Pericles, the son of Xanthippus, and one of Xanthippus himself, who fought against the Persians at the naval battle of Mycale. But that of Pericles stands apart, while near Xanthippus stands Anacreon of Teos, the first poet after Sappho of Lesbos to devote himself to love songs, and his posture is as it were that of a man singing when he is drunk. ${ }^{3}$

3 Translation after Jones 1918, 127

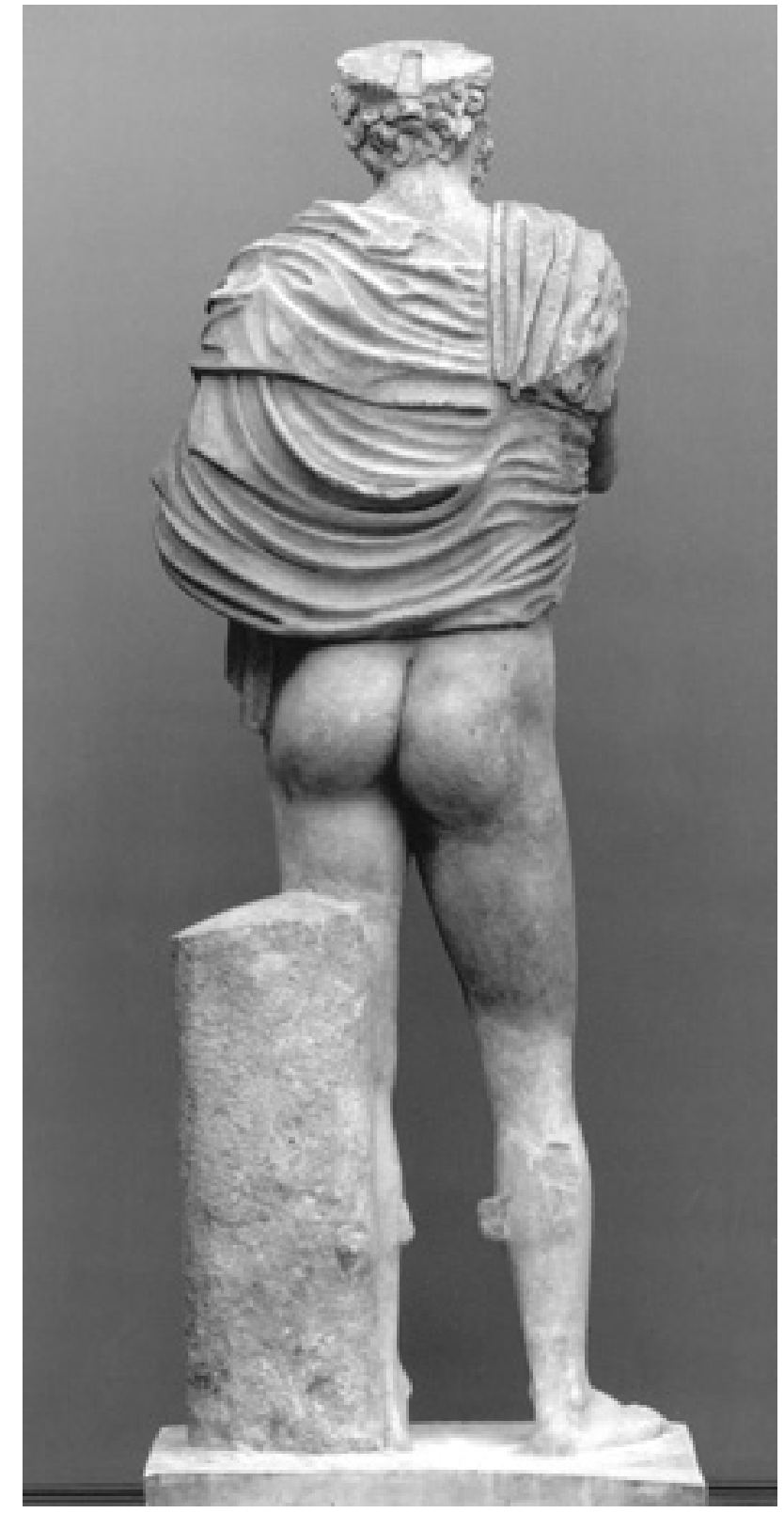

4 As Fig. 1: Back view 


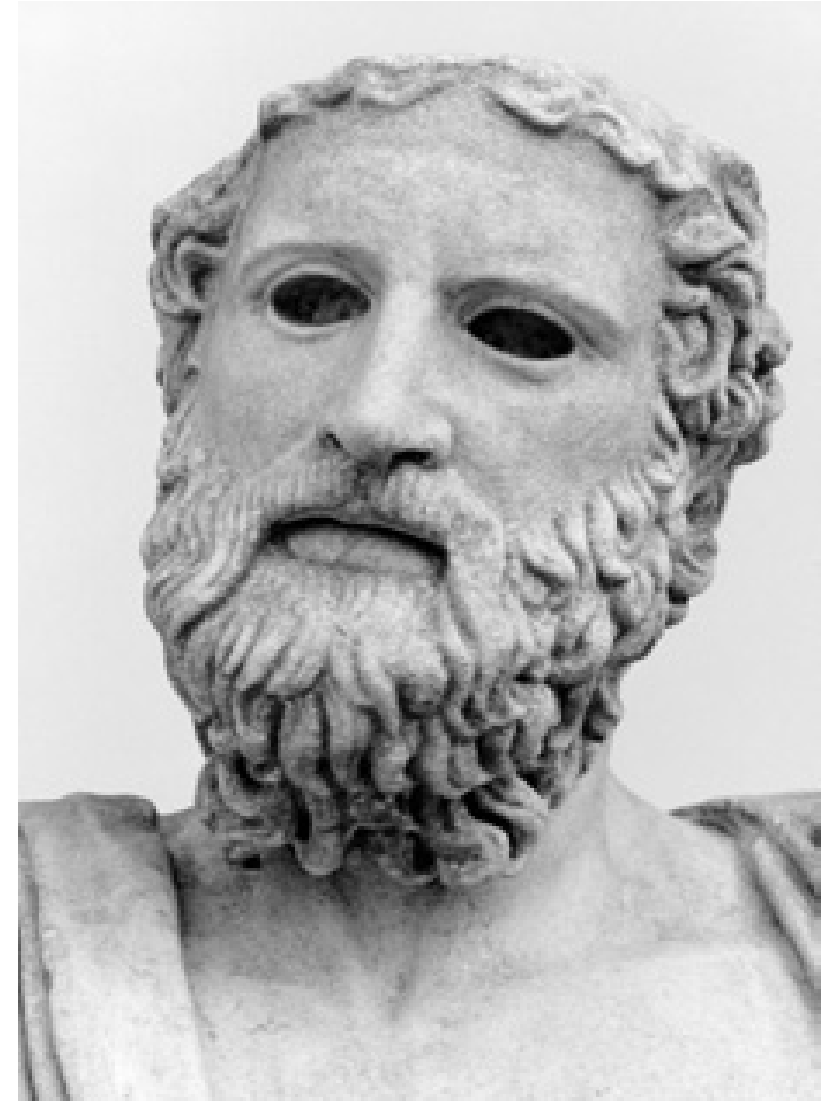

5 As Fig. 1: Detail of head

Furthermore, Anakreon's is the only portrait earlier than the fourth century B.C.E. ${ }^{4}$ for which we possess a full-body Roman copy; all the rest are known only from busts and herms. Thirdly, because Attic sculpture of the fifth century can be dated fairly closely on stylistic grounds, and the Copenhagen statue seems to be a faithful rendering of the original, there has seldom been

4 Henceforth all dates are B.C.E. unless otherwise stated.

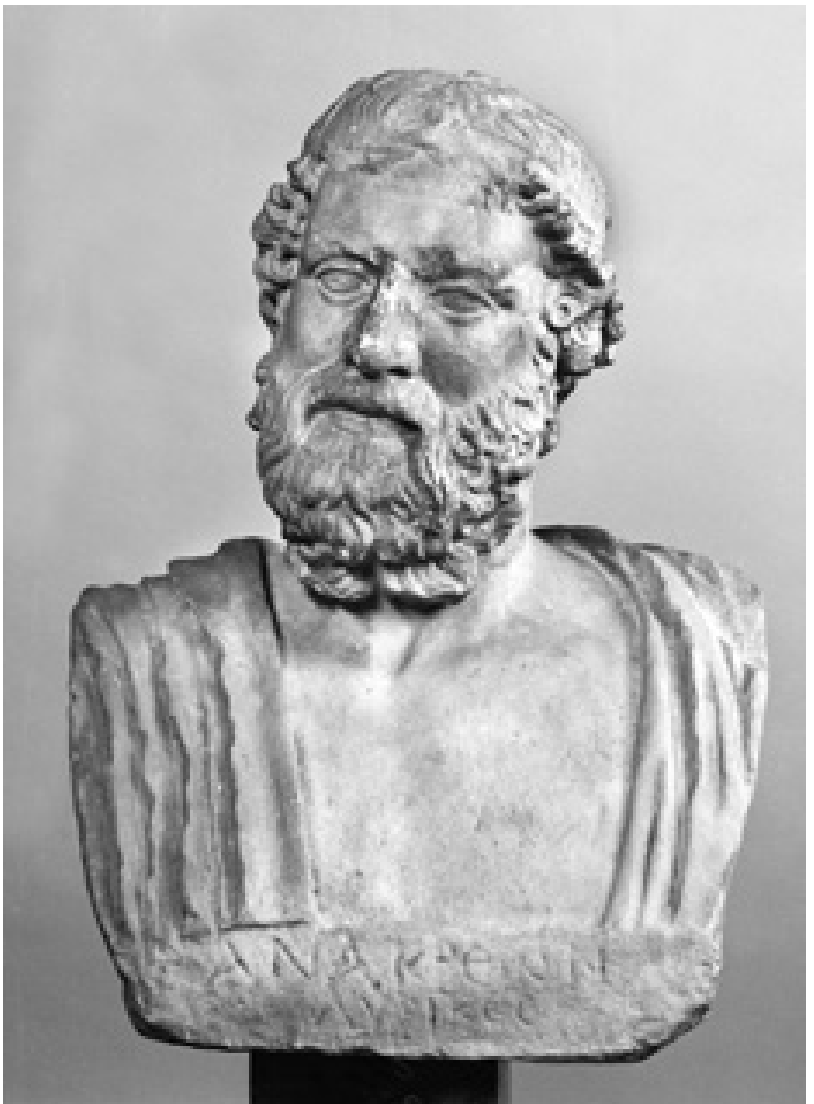

6 Rome, Palazzo dei Conservatori 838: Herm portrait of Anakreon

any serious disagreement about the dating of that original to the decade $450-440 .{ }^{5}$ Finally, all the extant copies of the head of Anakreon (nine in all) are close enough to both an inscribed herm (Fig. 6) ${ }^{6}$ and the Copenhagen statue to ensure that all go

5 Cf. Ridgway 1998, 732 n. 46, for a summary of variations in the dating, from the 460 's to the ca. 430 's. The great majority of scholars, however, agree on a date in the 440 's.

6 Rome, Palazzo dei Conservatori 838. The inscription says "Avak $\rho \dot{\varepsilon} \omega \nu$

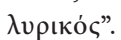


back to the same original. ${ }^{7}$ While there may have been other statues of Anakreon outside Athens, for example in his home town of Teos, which issued coins in his honor, ${ }^{8}$ there is, for most scholars, no difficulty in attributing all the known evidence to the Akropolis statue. A major exception to the communis opinio is Brunilde Ridgway, who, by thoroughly deconstructing all the evidence, attempts to show that there is no compelling reason to associate the Copenhagen statue with the Akropolis dedication, nor to date either one in the fifth century. She suggests several later periods when either could have been created. ${ }^{9}$ Though this is a salutary lesson in methodology (and as such the author intends her article), and in the pitfalls of making assumptions, I nevertheless believe that the traditional view is still the most likely working hypothesis, and for the purposes of this paper will assume that the Copenhagen statue is a reasonably faithful copy of a bronze original of the 440's that stood on the Athenian Akropolis.

With all this, there are still many other things about the statue that we are not told. For one, neither Pausanias nor any other ancient source tells us who the sculptor was. Given that the statue was a major commission in a very conspicuous location, the odds are good that he was one of the famous names of this period that have come down to us, and over the years since the late nineteenth century, the Anakreon has been attributed to virtually every one of the leading sculptors know to have been active in the mid-fifth century, by those scholars inclined toward Meisterforschung..$^{10}$ This question is, however, of lesser importance for our purposes here.

7 For all the copies, see Richter 1965, $76 \mathrm{f}$. The inscribed herm: Richter 1965, figs. 271. 272. 274.

8 Richter 1965, 77, for the Roman period coins of Teos. The existence of a statue in Teos is suggested by the epigram ascribed to Theokritos fr. 16 (= Anth. Pal. 9, 599), Richter 1965, 75.

9 Ridgway 1998.

10 The attribution to Pheidias, perhaps the one most commonly mentioned, goes back to Furtwängler 1893, $92 \mathrm{f}$. Cf. Voutiras 1980, 85 f. and, for other attributions, Richter 1965, 78 .
More importantly, we have no information on the circumstances of the statue's dedication: who put it up and why, or on what occasion. The statue would certainly have had an inscribed base containing at least some of this information, but we know nothing of the base. To contrast a later instance where we are even better informed than for Anakreon: the portrait statue of Demosthenes (also known in a famous full-length copy in Copenhagen) can be dated to the precise year, 280 , thanks to a passage in Ps.-Plutarch's Lives of the Ten Orators (Plut. mor. 847 a), and we also have recorded the epigram on the base. ${ }^{11}$ From this we may infer that the statue was set up in the Agora some forty years after the subject's death, probably by a member of his family, in an effort to rehabilitate the reputation of a public figure who had died a suicide in a dark period of the city's history, the aftermath of the Macedonian conquest. ${ }^{12}$

Coincidentally, the statue of Anakreon must also have been made just about forty years after his death, which we are told occurred, probably in Athens, about the year 487, at the ripe old age of eighty-five. ${ }^{13}$ But without the words on the base, we are in the dark about why the statue was set up at this moment in Athens's history, why in this most conspicuous spot in the city, just as the Parthenon was going up nearby, and what message it was meant to convey to visitors to the sanctuary. These are some of the questions I would like to address in this study.

11 See Richter 1965, 261 figs. 1398-1402, for the Copenhagen statue and von den Hoff 2009, for a recent discussion with earlier references.

12 On the historical background and the interpretation of the Demosthenes statue, see Zanker 1995, 85-89 and von den Hoff 2009.

13 For the sources, see Rosenmeyer 1992, 14. We are not told explicitly that Anakreon died in Athens, but Rosenmeyer and others consider it likely. See also Aloni 2000. 


\section{ANAKREON IN ATHENS}

According to one widely held view, the portrait of Anakreon was put up on the Akropolis either by Perikles himself or by members of his inner circle. ${ }^{14}$ An alternate view, most fully articulated by Emmanuel Voutiras, in a 1980 dissertation, and subsequently championed by his mentor Nikolaus Himmelmann, attributes the dedication of the statue to the conservative opposition to Perikles, who in so doing evoked the aristocratic values of the "Good Old Days" of Late Archaic Athens. ${ }^{15}$

Although we are nowhere told explicitly of an association with Perikles, as a scholarly hypothesis, this has a kind of inevitability about it. Pausanias remarks that the statue stood near one of Perikles' father Xanthippos $(1,25,1)$, with the implication that the two men were contemporaries and friends. ${ }^{16}$ Further, since the decade of the 440's was precisely when Perikles was at the zenith of his power and prestige in Athens, and when-as Plutarch tells it (Perikles 12-13) - he focussed much of his energy on a building program to revive and embellish the Akropolis after its destruction by the Persians, it is hard to imagine an otherwise unknown Athenian coming along and setting up an honorific statue that was in some way uncongenial to Perikles and his circle.

So goes the argument for Perikles as the one responsible for the portrait of Anakreon. Yet, as Voutiras rightly points out, it was only with the ostracism of Thucydides son of Melesias, leader of the oligarchic party, in 443 (Perikles 14, 3), that Perikles held unchallenged sway. And in the several years before that date, not only was the opposition to Perikles strong, but much of it (if we

14 Gauer 1968, 141 f.; most fully argued by Hölscher 1975.

15 Voutiras 1980, 90; Himmelmann 1990, 76 f.; restated in Himmelmann $1995,654-656$.

16 It should be stressed that this is the only source that links Xanthippos and Anakreon, and only by virtue of the proximity of their statues. See Hafner 1956; Krumeich 1997, 69-71. can believe Plutarch's account) was focussed on the Akropolis and Perikles' expensive and much-criticized building program (Perikles 12, 2). Thus the Akropolis would have been the natural spot for a private dedication expressing an opposing view. ${ }^{17}$ In order to evaluate the two positions, we need to consider in more detail just what the statue represented.

In addition to our good fortune in having a full-length sculptural version of Anakreon, we are also in the almost unprecedented situation of having likenesses of him, in another medium, made during his lifetime. Three red-figure vases of the years ca. 515-490 carry images of singers with the name Anakreon inscribed alongside or, in one instance, on his instrument (Figs. 7-8). ${ }^{18}$

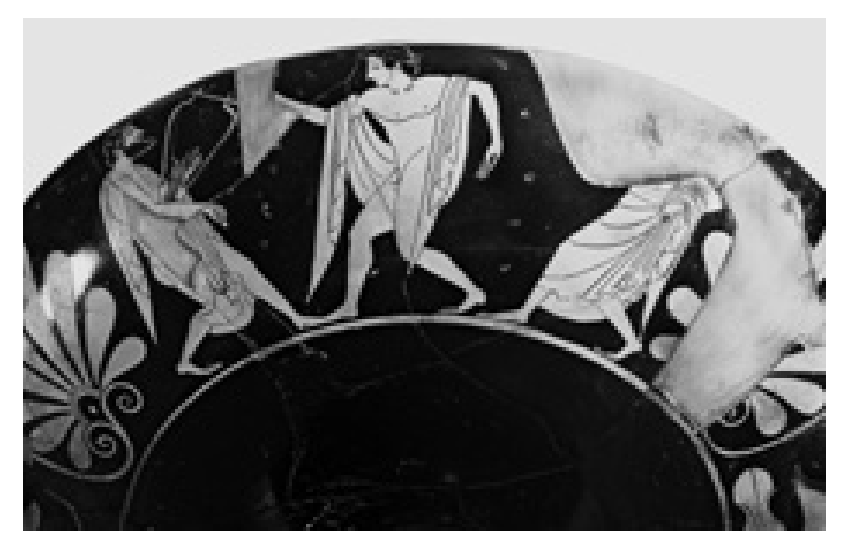

7 London, British Museum E 18: Red-figure cup depicting Anakreon

17 The statue was in any event a private dedication, since there were no public ones on the Akropolis before the early fourth century, Schäfer 2002, 289. Cf. Himmelmann 2001; Keesling 2003.

18 For the cups in London (Fig. 7) and Syracuse, see Schefold 1997, $76 \mathrm{f}$. and for the fragments in Copenhagen (Fig. 8), see Immerwahr 1965. On all three, see also Herington 1985, 198 f.; Rosenmeyer 1992, 15. 29-32; Schäfer 2002, 286 f. Following Papaspyridi-Karouzou, Richter adds a red-figure amphora that, however, has no inscription and could depict any of the 'Anacronies', Papaspyridi-Karouzou 1942/43, Richter 1965, 77. Likewise, Schefold adds a plate by Psiax with an unnamed Anacreontic musician, Schefold 1997, $78 \mathrm{f}$. 

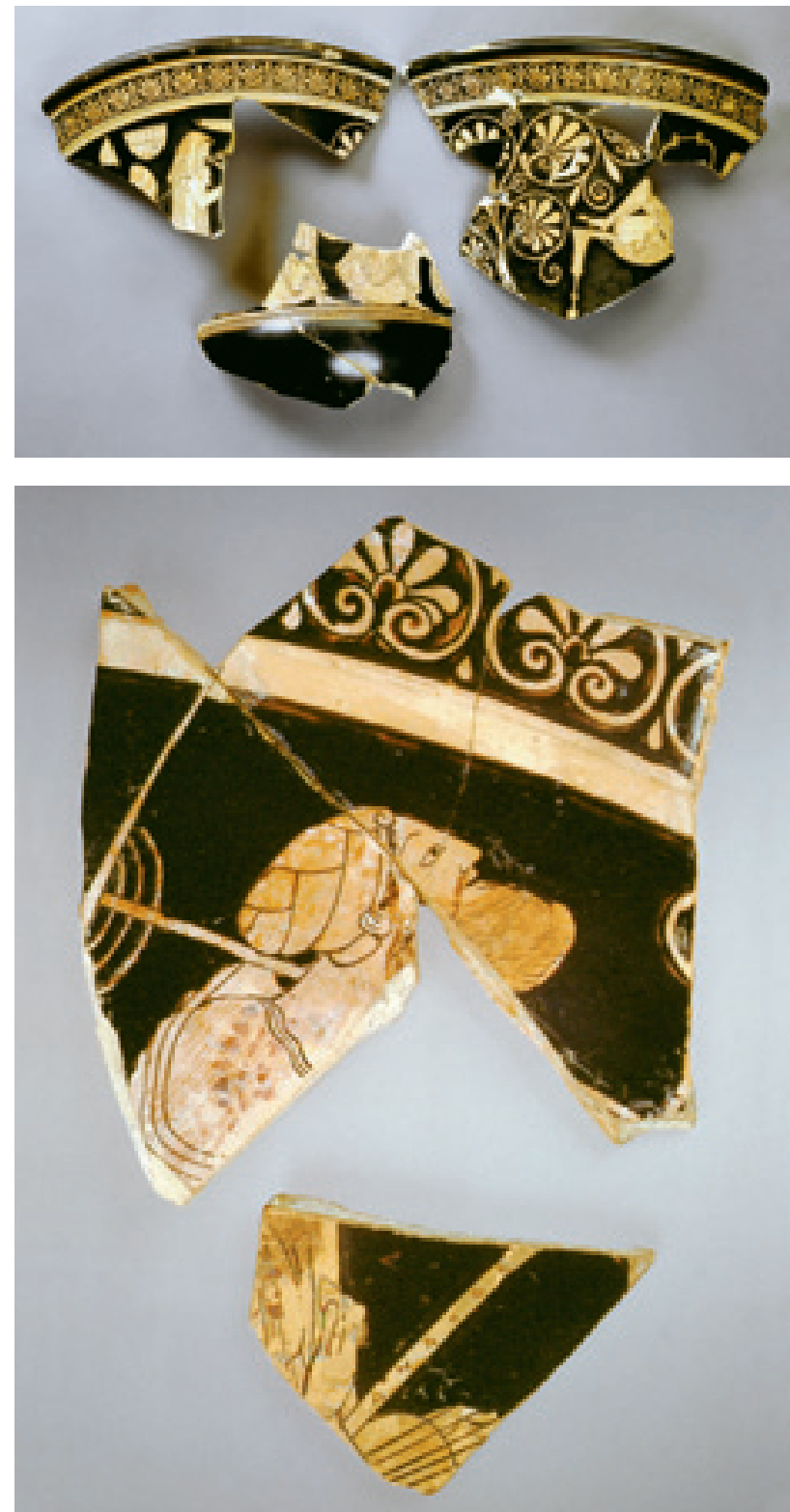

8 Copenhagen, National Museum 13.365: Red-figure krater fragments depicting Anakreon
Though the heads of these figures cannot in any sense be taken as eyewitness 'portraits' - they are indistinguishable from those of countless other bearded men of the period-the images nevertheless tell us much about how the poet was seen and remembered by Athenians of his day. In particular, he wears an elaborate long garment with other unusual attributes that betray his origins in Ionia, or East Greece. These include a kind of turban (known as either sakkos or mitra in archaeological parlance), boots, earrings, and a parasol. The fact that a sizeable group of vases of this period depicts small groups of komasts in this distinctive attire, but only Anakreon is actually named, has given rise to the idea that the Ionian poet caused a sensation with his exotic dress when he first came to Athens some years earlier (in 522) and many fashionable Athenians imitated his style. Thus, Sir John Beazley coined the witty term 'Anacronies' to describe the men thus depicted: friends and admirers of Anakreon..$^{19}$ Though some commentators have speculated that the costume is a form of transvestism, ${ }^{20}$ Keith DeVries first demonstrated in the 1970's that it is fully comprehensible as (male) East Greek dress, ${ }^{21}$ and Donna Kurtz and John Boardman subsequently reinforced this conclusion in a meticulous study of every individual element of the costume.22

For our study of the Anakreon statue, the main value of the vases is to make clear how radically re-imagined the mid-fifth century image of the poet was from the one that was current in his lifetime. ${ }^{23}$ Where the Anakreon of the vases is swathed in voluminous layers of clothing and conspicuous headgear, the statue is nude but for a short garment thrown like a shawl over the shoulders, and the head carries only a wide but discreet fillet.

19 On the 'Anacronies', see Caskey-Beazley 1954, 55-61 and, of many more recent discussions, see Price 1990; Frontisi-Ducroux-Lissarrague 1983; Delavaud-Roux 1995.

20 Miller 1999 is the fullest and most recent statement of this argument.

21 DeVries 1972/73.

22 Kurtz-Boardman 1986.

23 Becatti 1951, 149, who attributes the radical re-invention of Anakreon's image in the Akropolis statue to the originality of Pheidias. 
The question of the statue, then, is not only what messages it was intended to project, but also what aspects of the subject it was trying to suppress.

Of the latter, the most obvious would be any association with the institution of tyranny. It was, after all, Hipparchos, the younger son of the Athenian tyrant Peisistratos, who brought Anakreon to Athens, rescuing him from Samos, where he performed at the court of yet another tyrant, Polykrates. ${ }^{24}$ The flamboyant attire of the poet may be a kind of professional costume of the East Greek performer, but it also inevitably smacks of the luxury associated with tyrants anywhere in the Greek world. As an apolitical artist, and a hugely popular one at that, Anakreon will have survived the fall of the Athenian tyrants with his reputation untarnished, and all the evidence suggests that he remained popular during the early years of the democracy and down to his death three years after Marathon. Two of the three images of him on vases are almost certainly later than the expulsion of Hippias in $510 .{ }^{25}$ Nevertheless, it may be significant that there is no hint of tyrannical luxury in the classical portrait statue.

Equally obvious, and even more striking, is that there is also no hint of Anakreon's East Greek origins in the statue. If his Ionian 'haute couture' was what impressed the Athenians of his day in his public performances, the removal of these trappings from the Akropolis statue seems designed to present him as an 'honorary Athenian' whose city of origin was less important than the fact that he made his home in Athens for nearly forty years and achieved his greatest fame there.

24 For the sources on Anakreon's stay on Samos and his coming to Athens (Plat. Hipparch. 228 b), see Rosenmeyer 1992, 12 f.; Bowie 2009, 127-130.

25 Only the cup by Oltos (Fig. 7 ) is certainly earlier than 510 . See PapaspyridiKarouzou 1942/43, who suggests that Anakreon may have followed Hippias into exile in Thessaly, but was back in Athens by 500 or soon after. See Herington 1985, 110 f., for the interesting suggestion that Anakreon could have known and influenced the young Aischylos in the years around 500 in Athens. I thank Joel Lidov for this reference.
Recent commentators have mostly agreed that Anakreon's nudity characterizes him as an Athenian symposiast, a type best known from hundreds of red-figure vases depicting nude, bearded komasts dancing, singing, and carousing after a symposium. ${ }^{26}$ But not just any symposiast. Though both forearms and hands are missing from the Copenhagen copy, it is generally assumed that Anakreon was holding a light stringed instrument, the barbitos, playing as he sings with gently parted lips. ${ }^{27}$ There are indeed many komasts who hold the easily portable barbitos, but in Anakreon's case, the instrument is more than just a casual attribute; it is a specific reference to his profession. ${ }^{28}$

\section{NUDITY AND INFIBULATION}

The most intriguing aspect of the statue remains its nudity. Even the garment, clinging tightly to the sides of the chest and shoulders, serves more to set off and call attention to the nudity than to cover it. $^{29}$ The proportions of the body are highly idealizing, essentially the same as those of mature gods and heroes of the period, such as the Zeus of Artemisium or the Riace Warriors. Werner Gauer detected subtle indications of a mature man in the slightly relaxed treatment of the musculature and the lack of tautness of the limbs

26 See especially Zanker 1995, 29-32; Brusini 1996; also Himmmelmann 1990, 77, who, in contrast to Zanker, speaks of Anakreon's "Sorglosigkeit und Ausgelassenheit" as expressed in the nudity.

27 For the reconstruction with the musical instrument, see especially Brusini 1996. Cf. the well-known image of Sappho and Alkaios, each holding the barbitos, on a somewhat earlier vase in Munich, Schefold $1997,84 \mathrm{f}$.

28 A point stressed by Himmelmann in an effort to balance Zanker's too great emphasis on the symposiast aspect at the expense of the poet, Himmelmann 1995, 654-656; Zanker 1995, 32.

29 The closest comparison for the garment on a statue of the fifth century is the Oinomaos from the East Pediment at Olympia, Ridgway 1998, 733-735. She refers to this garment as a chlaina. 
in comparison to statues of young athletes. ${ }^{30}$ But the clearest indication of a mature man is the very full beard, which looks even fuller than most, because the upward tilt of the head exposes slightly unruly locks of beard on the neck (cf. Fig. 5). This may be the only explicit reference to the high age that Anakreon attained.

Some fifteen years ago, Paul Zanker called attention to a detail of the statue that had been noted but seldom discussed in detail, and thereby initiated a new phase in the interpretation of its nudity. This is the treatment of the penis, with the foreskin tied up in the practise known to the Greeks as kynodesme and usually translated as infibulation. ${ }^{31}$ Since this feature is extremely rare in statuary of the Classical period, and not especially common on vases, it is clearly quite deliberate and significant, and no interpretation of the statue's nudity can ignore it. Frederik Poulsen, who first published the statue in detail, adduced an ancient source stating that musicians should be infibulated, as this allegedly improves the voice. ${ }^{32}$ For Zanker, the infibulation is, first, a sign of the subject's advanced age, when a man's sexual organ could become misshapen and unattractive, better kept firmly tied up and immobilized. Secondly, according to Zanker, it expresses the self-restraint of the dignified symposiast. This approach was recently elaborated by Jens Daehner, who argues that by the time our statue was made in the 440's, nudity for mature (i.e. full-bearded) men had become 'problematical'. The infibulation only serves to underline the point. ${ }^{33}$

30 Gauer 1968, $141 \mathrm{f}$.

31 Zanker 1995, 34 f.; earlier discussed by Poulsen 1931, 13-15; Voutiras 1980, 89. Cf. Daehner 2005, 284-286. 285 n. 486 , with reference to a study by a historian of medicine. The pubic hair around the penis is now curly and naturalistic, unlike the stylized and trimmed pubic hair of Archaic nude statues. See Smith 2007, 112-116.

32 Poulsen 1931, 13-15; Voutiras 1980, 89.

33 Daehner 2005, 285; cf. 294, where Daehner suggests that both the infibulation and the garment make Anakreon's nudity 'conditional' because, for a mature man, nudity is no longer an "ästhetisch selbstverständliches Konzept”. As Daehner observes, infibulation is found in only a very small number of surviving statues, all of them Hellenistic or Roman and all of bearded men and (interestingly) satyrs.

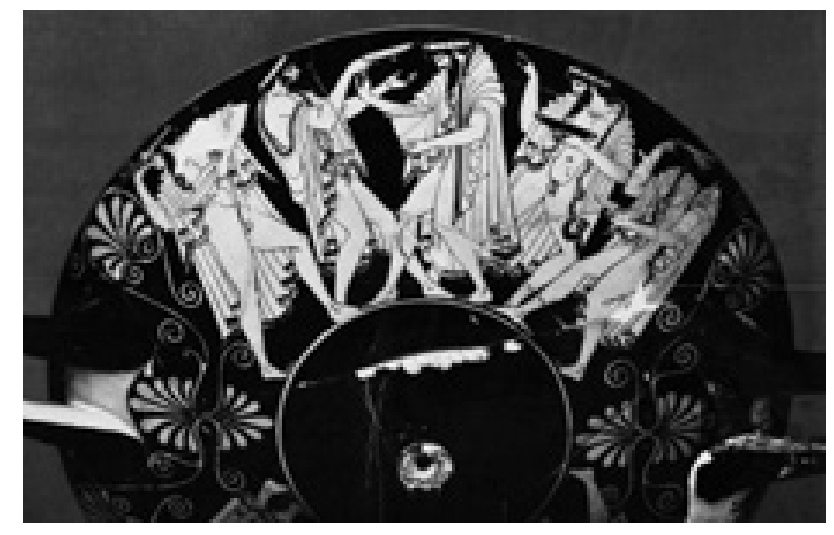

9 London, British Museum E 53: Red-figure cup, Side B

A brief look at depictions of infibulated figures on Attic vases earlier than the Anakreon statue does not reveal a consistent pattern. It is often assumed that the practice was mainly associated with young athletes who exercised nude in the palestra, either to protect the penis during rough sports or to discourage it from becoming erect. ${ }^{34}$ But more relevant to our context are several drinking cups depicting groups of bearded komasts, of whom one is shown infibulated. On a cup in London, for example (Fig. 9), ten bearded men, spread over both sides of the exterior, participate in a komos, all but one so lightly dressed that their genitals are exposed. ${ }^{35}$ The man in the middle of Side B, who carefully carries a skyphos filled with wine, is infibulated. ${ }^{36}$ Still, if nudity is problematical

34 Sweet 1987.

35 London, British Museum E 53. ARV ${ }^{2}$ 435, 87; CVA London, British Museum (9) pl. 33.

36 Cf. the tondo of a second cup in London, British Museum E 54, by the same painter (Douris) with two komasts, the one carrying a jug and a skyphos also infibulated. $\mathrm{ARV}^{2}$ 436, 96; CVA London, British Museum (9) pl. 35. One wonders whether the infibulation echoes the soberness and concentration needed to walk while carrying vessels filled to the brim with wine without spilling them. See the comments of Williams, in CVA London, British Museum (9) 38. Zanker compares a representation of an infibulated bearded komast on a vase contemporary with the statue of Anakreon, Zanker 1995, 37 fig. 18. 
for a man of Anakreon's age, and has to be mitigated by the infibulation, then why portray him nude in the first place?

\section{ANAKREON AND THE SYMPOSIUM}

Perhaps we need to consider more closely what associations Athenians of the 440's will have had with the historical figure of Anakreon. The oldest of them may have even remembered seeing him when he was very old and they were very young. But for the rest, it was chiefly his poetry that was remembered, along with various anecdotes about his life that have been transmitted to us chiefly by much later sources. ${ }^{37}$

A recent, thoughtful analysis of the Anakreon statue, by Alfred Schäfer, emphasizes his role not only as a participant in the symposium, but as a singer about the symposium. ${ }^{38}$ That is, he is to be imagined as singing the pleasures of wine, but in moderation, kept under control (like the infibulated penis). This approach responds to the earliest recorded reaction to the Akropolis statue, that of Pausanias, who, as we've seen, observes that Anakreon's pose (schema) "looks like one who is singing while drunk" $(1,25,1)$. With this offhanded comment, Pausanias set off a debate that continues to rage among scholars. Some have accused the periegete of blatantly misrepresenting the statue, asserting that its stance is firm and steady, in a contrapposto that is perfectly standard for the period in which it was made. ${ }^{39}$ Others have seen Anakreon gently swaying in time to the music, though not necessarily inebriated. ${ }^{40}$

37 Rosenmeyer 1992, 12-15.

38 Schäfer 1997, 88. For Anakreon's sympotic poetry, particularly on the dangers of drinking in excess, see Rosenmeyer 1992, 18; Lissarrague 1990, $90 \mathrm{f}$.

39 Schäfer 1997, 88. However, Schäfer concedes that, in a side view (Fig. 2), the figure's stance has a slight wobble, indicating that he is tipsy, Schäfer 2002, 288.

40 Gauer $1968,141 \mathrm{f}$., who believes the effect of the wine is referred to very discreetly, like the signs of age.
Some have even agreed with Pausanias, ${ }^{41}$ while others have been convinced by the passage that Pausanias was looking at a different statue. ${ }^{42}$ We will never know the exact intention of the sculptor, but I incline to the view of Voutiras that Anakreon is to be understood as seized by the enthousiasmos of the divinely inspired poet. ${ }^{43} \mathrm{We}$ have several vase depictions of professional musicians, especially kitharodes, who throw their heads back in a more exaggerated version of Anakreon's pose, to show how they are possessed by the music they make. ${ }^{44}$

That Anakreon was remembered throughout the fifth century and beyond as the poet of the symposium par excellence is clear from many sources. ${ }^{45}$ One of the most significant of these is a 10-line epigram in honor of Anakreon, composed some time in the later fifth century by Kritias, the grandson of a man also named Kritias who was said to have been a friend, or even a lover, of Anakreon. ${ }^{46}$ The poet Kritias would end his life as one of the notorious Thirty Tyrants (as well as being Plato's uncle), and his strongly anti-democratic sentiments could be seen as an argument in favor of the statue as an oligarchic dedication. We shall return to this point below, but for now, it suffices to observe that the symposium looms large in Kritias's poem, which describes Anakreon as the "catalyst of the symposium" and asserts that his memory will never die as long as proper symposia continue to be held. ${ }^{47}$

41 Schefold 1997, 102; Metzler 1971, 264-267.

42 See Ridgway $1998,726 \mathrm{f}$

43 Voutiras 1980, 88

44 E.g. the well-known amphora by the Berlin Painter in New York, Metropolitan Museum of Art 56.171.38. ARV ${ }^{2}$ 197, 3; v. Bothmer 1972-1973, fig. 17. And the amphora of panathenaic shape formerly in New York and now in Rome, Godart-De Caro 2007, 90 f. Cf. Shapiro 1992, on depictions of kitharodes.

45 Bowra 1961, 275-277; Rosenmeyer 1992, 33. 38; Schäfer 1997, 88.

46 For the family of Kritias, see Davies 1971, 322-327. Cf. Plat. Charm. 157 e. The Scholium on Aeschylus' Prometheus 128 says that Anakreon was in love with the elder Kritias when he came to Athens. Kritias was a candidate for ostracism in the 480 's.

47 Kritias fr. 500 PMG (= Athen. 13, 600 d-e). See Rosenmeyer 1992, 16 f., for text, translation and discussion. 
The contrast between Anakreon and the kitharoidoi depicted on vases adds support to the idea of Anakreon as an exclusively sympotic poet and singer. The kitharodes are always dressed in the long, elaborate garment of the professional singer who performed in public and competed at festivals such as the Panathenaia at Athens. While such contests had been part of the festival at least since the time of Hipparchos, and probably a good deal earlier, ${ }^{48}$ it is also true that by the mid-fifth century, there was an increasing professionalization of these performers. ${ }^{49}$ The paradigmatic example, a generation later, is the rhapsode Ion, who is gently made fun of by Plato, in the dialogue bearing his name, as a canny professional with little of the divine inspiration of his Archaic predecessors. But Anakreon's dress (or lack of it) makes clear that he does not belong to this class of public performers, which would have included such contemporaries of his as Stesichoros. ${ }^{50}$ Rather, his performances took place only in the purely private setting of the élite symposium. The distinction was particularly essential in the Periklean period when the statue was put up, as we have good reason to believe that under Perikles' influence, the mousikoi agones at the Panathenaia became even more prominent and perhaps subject to new regulations. ${ }^{51}$ It is also likely that these performances received a new and very conspicuous home, with the building of the Odeion on the South Slope of the Akropolis..$^{52}$ Anakreon, with his nudity and with the light-weight barbitos that we may restore in his hands (not the professional kithara), ${ }^{53}$ asserts the continuing place of honor

48 Kotsidu 1991, 27-34; Shapiro 1993, for the introduction of these contests as early as the reorganization of the Panathenaia in 566.

49 See Bundrick 2005, 80-92, on professional musicians.

50 On Stesichoros, see Burkert 1987. It is likely that both Ibykos and Simonides at times entered competitions for the performance of epic. See Bowie 2009, 134.

51 On the musical contests in the time of Perikles, see Shapiro 1996a; Tiverios 1989

52 Hurwit 1999, $216 \mathrm{f}$.

53 Cf. also Brusini 1996, who suggests that the statue held the instrument resting on his hip and held a drinking-cup in the right hand. of the old-fashioned bard, who does not compete for money or prizes, but performs for the pleasure of his aristocratic patrons and the glory of his art.

\section{SYMPOSIUM AND PEDERASTY IN THE AGE OF PERIKLES}

The ongoing centrality of the symposium in the lives of wealthy Athenians is a somewhat unexpected feature of the radical democracy of Ephialtes and Perikles. Certainly this is still true of the world that Plato and Xenophon describe in the late fifth and early fourth centuries, and a long and unbroken series of red-figure vase-paintings stretching through the whole of the fifth century can help to bridge the gap from the Archaic heyday of the symposium to the period of these much later authors. ${ }^{54}$ In fact the overall consistency of symposium iconography in Athens over nearly two centuries, despite subtle shifts of emphasis here and there, speaks for an institution that was remarkably conservative and long-lasting, and relatively unaffected by the political vicissitudes of the city.

The same is true, I shall argue, of the institution of élite pederasty, which was intimately bound up with the symposium..$^{55}$ The distinctive imagery of the symposium in the age of Perikles and its portrayal of erotic themes may offer another clue to the interpretation of the statue of Anakreon. A survey of symposium scenes on vases of the second and third quarters of the fifth century reveals a striking tendency to limit the participants to pederastic couples, typically two pairs of bearded man and beardless youth on adjacent klinai (Fig. 10), ${ }^{56}$ or one pair of man and

54 For diachronic studies of the symposium and its iconography, see Schäfer 1997 .

55 Bremmer 1990; Stähli 2001.

56 London, British Museum E 495. ARV² 1045, 8; Matheson 1995, 432 cat. L8. 


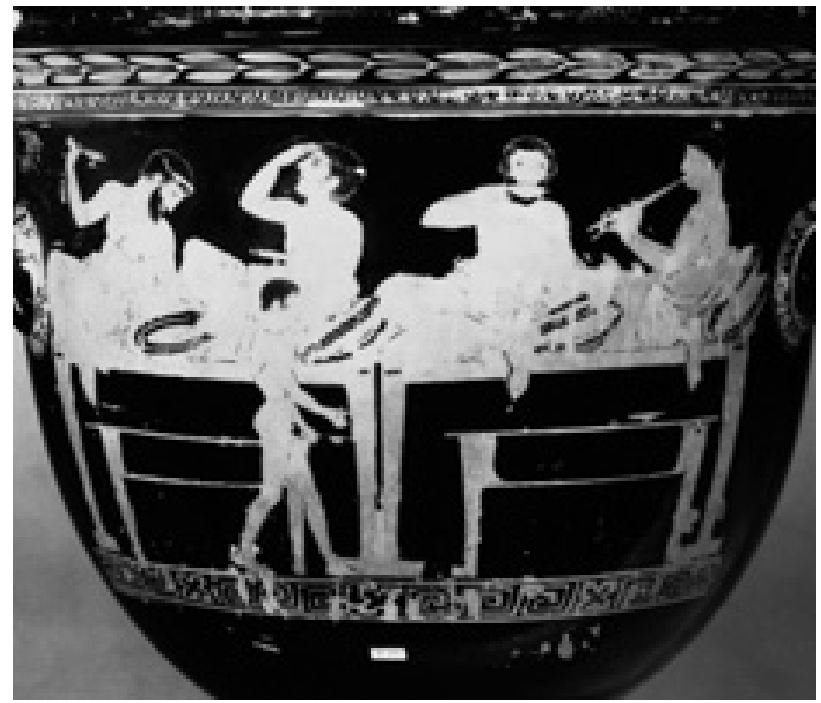

10 London, British Museum E 495: Red-figure bell-krater, Side A

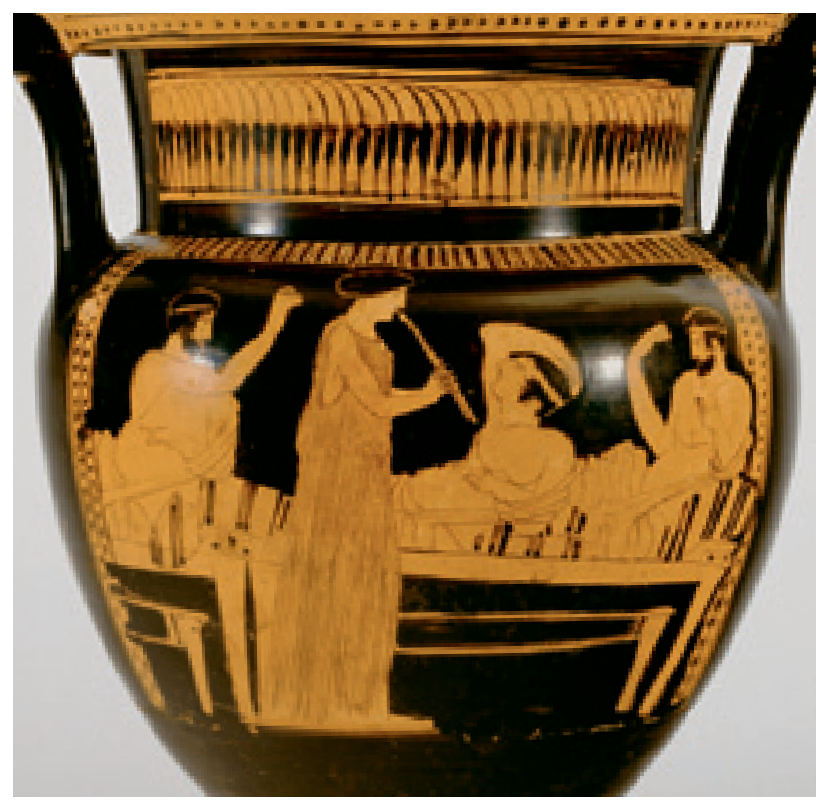

11 Baltimore, Walters Art Museum 48.67: Red-figure column-krater, Side A youth with a youth or man alone on the second couch (Fig. 11).57 The only female presence is now an aulos-player, who is usually quite modestly dressed and is not always included (cf. Fig. 11) ${ }^{58}$ The hetairai, whether nude or elegantly dressed, who share the kline with their gentleman admirers on Archaic vases are now, with few exceptions, conspicuous by their absence..$^{59}$ This trend toward a kind of homoeroticizing of symposium imagery in the Classical period seems at first glance to be at odds with another iconographical development that has often been observed on vases of the same period, namely, the abrupt disappearance of the pederastic courting scene.

Between ca. 560 and 475, the scene of a bearded erastes wooing his young eromenos, whether with gifts or with importuning gestures or, as a consummation, in a form of intercourse termed by Beazley "intercrural", is a consistently popular feature of the black- and early red-figure repertoire. ${ }^{60}$ Certain developments can be observed, such as a gradual youthening of the erastes in the late sixth century, to an adolescent youth barely older than his beloved, but otherwise, the typology established by Beazley on the basis of black-figure vases of the mid-sixth century remains remarkably consistent over several generations. Yet soon after 480 the subject is no longer to be found, or is replaced by

57 Note the striking contrast between Athenian symposia and the iconography of the symposium of Olympian gods, such as a cup by Makron (Kunisch 1997, pl. 119); a krater by the Troilos Painter (Padgett 2002); or the cup by the Codrus Painter in London, British Museum E 82 $\left(\mathrm{ARV}^{2}\right.$ 1269, 3; Avramidou 2006). On this cup, ten gods are spread over the three surfaces of the cup, always sharing klinai in pairs of male and female (Zeus/Hera, Poseidon/Amphitrite, Dionysos/Ariadne, Hades/Persephone, and even the adulterous couple Ares/Aphrodite). Though pederastic relationship are hardly unknown among the gods (Ganymede also appears as a serving-boy on this cup, beside Zeus), for 'official' purposes each god has a female consort. The symposium of Athenian men serves an entirely different purpose.

58 Baltimore, Walters Art Museum 48.67. ARV 2098, 29; CVA Walters Art Gallery (1) pl. 17 .

59 See Peschel 1987, 211-230. 328-332.

60 Beazley 1989, 19-22. 24 f.; Lear-Cantarella 2008, 107-111. 
mythological versions such as Zeus and Ganymede. ${ }^{61}$ Those who incline to political-historical explanations, including the present writer, have speculated that under the young Athenian democracy, the pederastic courtship carried an unwanted reminiscence of the age of the tyrants when it had especially flourished: not that the institution of pederasty as such died out, but that explicit depictions of it were no longer deemed acceptable under the democracy. ${ }^{62}$ Nor is this form of social pressure limited to homosexual behavior, for the crass depictions of men having intercourse with hetairai, which experienced a great vogue in red-figure between the last years of the sixth century and ca. 470, soon disappear equally suddenly. ${ }^{63}$

The physical setting for the pederastic encounters of the Archaic period, where it can be determined by the presence of such attributes as sponge, strigil, or aryballos, seems to be the gymnasium or palestra, where men and boys exercised in the nude. ${ }^{64}$ In other instances, where such utensils are not present and several couples of erastes and eromenos comprise a kind of restrained orgy (to use an oxymoron), we may think rather of the komos that followed a symposium..$^{65}$ The depiction of the symposium itself, which is well-established in Attic black-figure by the middle of the sixth century, also sometimes features same-sex couples alongside the more common motif of the hetairai with their clients. ${ }^{6}$

In the early years of Anakreon's sojourn in Athens, ca. 515, Euphronios's superb rendering of a symposium, on a big calyxkrater now in Munich, features two pairs of man and youth on

61 Frel 1963. See Lear-Cantarella 2008, 175-177, who show how the Archaic scenes of courtship are replaced by other iconographies in later periods.

62 Shapiro 1981, $141 \mathrm{f}$. For a different view, see Kilmer 1997.

63 Kilmer 1993, 2.

64 Schauenburg 1965

65 E.g. the well-known amphora London, British Museum W 39. ABV 297 , 16; Shapiro 1981, pl. 25 figs. 4. 5. See Lear-Cantarella 2008, 65 f.

66 Schäfer 1997, 38-40. adjacent klinai (Fig. 12). ${ }^{67}$ Three youths who fetch more wine from a dinos on the reverse of the krater, two of them completely nude, add to the homoerotic ambience. The only female presence is the aulos-player Syko, but her demure costume and advanced age, indicated by a double chin, suggest that her services are only of a musical, not a sexual, nature. The interactions of the two couples and their varying reactions to the music are finely observed.$^{68}$ The two younger men turn directly toward the musician, while the two older are absorbed in themselves: one sipping from his wine-cup and looking out at the viewer; the other throwing back his head as he bursts into song. The words of the song issuing from his mouth, apparently a hymn to Apollo, Artemis and Leto, have

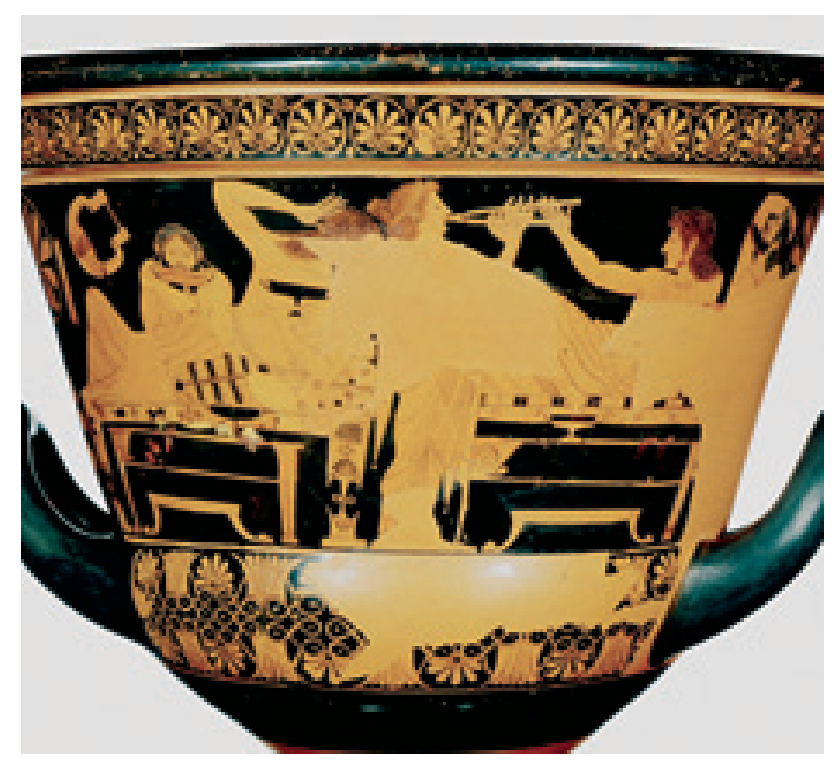

12 Munich, Staatliche Antikensammlungen 8935: Red-figure calyx-krater, Side A

67 Munich, Staatliche Antikensammlungen 8935. ARV² 1619, 3 bis; Giuliani-Heilmeyer 1991, no. 5.

68 Vierneisel 1991. 
been associated with Anakreon. ${ }^{69}$ Intimacy between the partners is not the picture's major theme, though the chiastic arrangement of beardless and bearded is certainly deliberate and anticipates by half a century the pederastic couples on Classical symposium vases. All four carry names of Euphronios's (and Anakreon's) contemporaries, including his fellow painter Smikros as one of the youths. ${ }^{70}$

This very Smikros would depict himself, just a few years later, in an elaborate symposium scene that can be read as his answer to the slightly older Euphronios. ${ }^{71}$ Here Smikros portrays himself in a markedly heterosexual context, with the youth on each kline (himself and another called Pheidiades) accompanied by a partially clad hetaira, one couple in an embrace. It is as if the two vases and their authors, who were well acquainted, engage in a dialogue on the relative merits of same-sex and heterosexual love. An actual treatise on this topic appears many centuries later attributed to Lucian. ${ }^{72}$ What is clear in the comparison of the two vases, and consistently in others of the period, is that the male same-sex couples are quite restrained in their behavior vis-à-vis the erotic intimacy of the male-female couples. It is the difference between upper-class men with hired prostitutes versus citizen males of the same class.

The years about 500-470 are a period of transition for the imagery of the symposium. Scenes of erastes and eromenos sharing the kline, in the tradition of Euphronios, are now quite rare, while those of men and their hetairai, in the tradition of Smikros, continue to enjoy popularity, especially in the work of Makron. ${ }^{73}$

At the same time, a new iconography offers a different scenario, which falls somewhere between the homoerotic and the heterosexual options of the Pioneer generation. In these scenes, most often on cups but sometimes on larger shapes as well, the

69 Vermeule $1965,38 \mathrm{f}$

70 Neer 2002, 111-115.

71 Brussels, Musees Royaux A717. ARV² 20, 1; Neer 2002, 87-91. 96-102.

72 Lukian. Amores. Translation after Hubbard 2003, 505-531.

73 Kunisch 1997, 113-115.

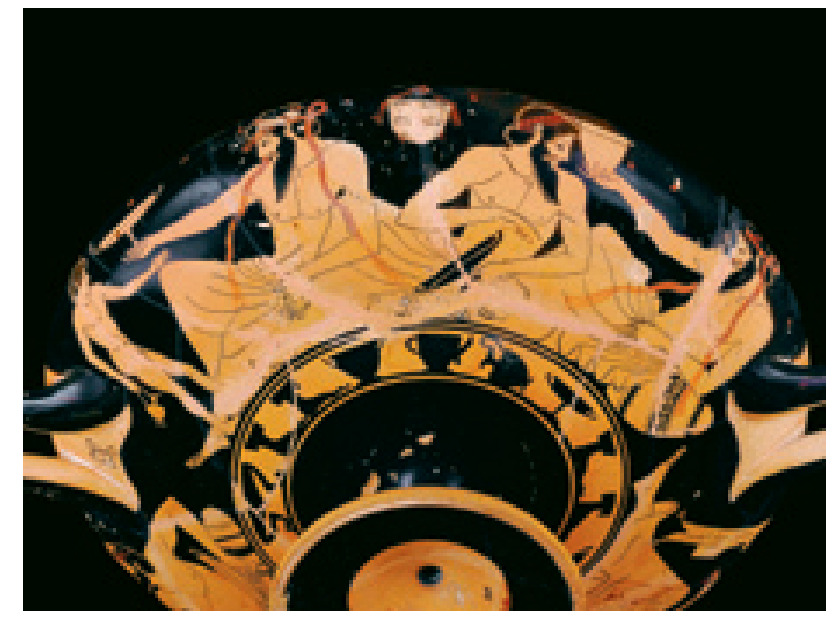

13 London, British Museum E 64: Red-figure cup, Side B

symposium participants are all mature men with full dark beards (Fig. 13).$^{74}$ In Greek terms, there is no overt eroticism, since the young eromenos, or love-object, is missing, nor are any women ever present. At most the presence of naked serving boys may add a slight sexual frisson (cf. Fig. 13), ${ }^{75}$ but in general these boys are too young to be of interest. Since these men are usually not reclining on klinai, the scenes may derive from a group of black-figure cups of the late sixth century that depict gatherings of bearded men having a kind of picnic in an outdoor setting. ${ }^{76}$ The Euphronian motifs of music, poetry and song are all present (even the inspired man with head thrown back and hand to head), but these drinkers can only imagine the absent objects of their affection. These are hinted at in the inscription that is often repeated on both sides: "HO ПAI $\Sigma$ KA $\Lambda \mathrm{O} \Sigma$ " - "the boy is beautiful", suggesting the subject of the songs, like some of

74 E.g. London, British Museum E 64. $\mathrm{ARV}^{2}$ 455, 9 (Ashby Painter), ca. 500; CVA London, British Museum (9) pl. 23.

75 E.g. London, British Museum E 49. ARV ${ }^{2}$ 432, 52 (signed by Douris); CVA London, British Museum (9) pl. 29.

76 Topper 2009; Heinrich 2007; Yatromanolakis 2009. 
those composed by Anakreon (see below). A touch of suggestive humor is added by one of the silhouette vases in the predella on Side B of the Ashby Painter's cup, a skyphos with spout in the shape of a phallos (cf. Fig. 13). ${ }^{77}$ Complementing these symposia is a series of cups, often by the same painters, showing the rowdy komos that followed the symposium, with all the participants likewise bearded men (cf. Fig. 9). ${ }^{78}$

By the decade $480-470$, all of these scenes - the heterosexual symposium, the all-male symposium and komos, the sexual encounter of hetaira and customer, the courting of an eromenos by his erastes-have been eclipsed by a new range of mainly mythological subjects in the wake of the Persian Wars, never to return to the painters' repertoire in the case of the explicit sex scenes and the pederastic courtship, ${ }^{79}$ in a different guise in the case of the symposium and komos. To reiterate the essential point, the symposium with bearded/beardless couples on adjacent klinai, which had not been seen since Euphronios's Munich krater (cf. Fig. 12), experiences a sudden revival starting in the 460's and exploding into a highly popular motif in the following decade (cf. Figs. 10-11), becoming a hallmark of the entire Periklean period down to the 420's.

The predilection for all-male symposia with a strongly pederastic flavor on red-figure vases of the High Classical period is, then, not incompatible with the disappearance of male courtship scenes, but complementary to it. That is, while the depiction of the sexual act, in any form, is now seen as inappropriate to the elevated self-consciousness of the Athenians of the post-Persian era, the ongoing, and perhaps even more idealized role of the erastes-eromenos relationship is expressed no longer in the milieu of the palestra (where most of the courting scenes seem to be set), but in that of the symposium.

77 For other examples, see CVA London, British Museum (9) pl. 24 78 Discussed above p. 22-24 and n. 36, for the infibulated komast. 79 Sutton 1992. Cf. Meyer 1993.
The earliest examples of this scene can be traced to the decade 470-460, for example on a cup attributed to the Euaion Painter in Geneva (Figs. 14-15). ${ }^{80}$ On each side of the cup's exterior, pairs of men and youths share two klinai. The all-male ambience and erotic subtext are further emphasized by the substitution of a nude male aulos-player for the more usual female, on one side, and a robust, nude serving boy (hardly a pais anymore), his nude body shown nearly frontal, on the other. One of the bearded men
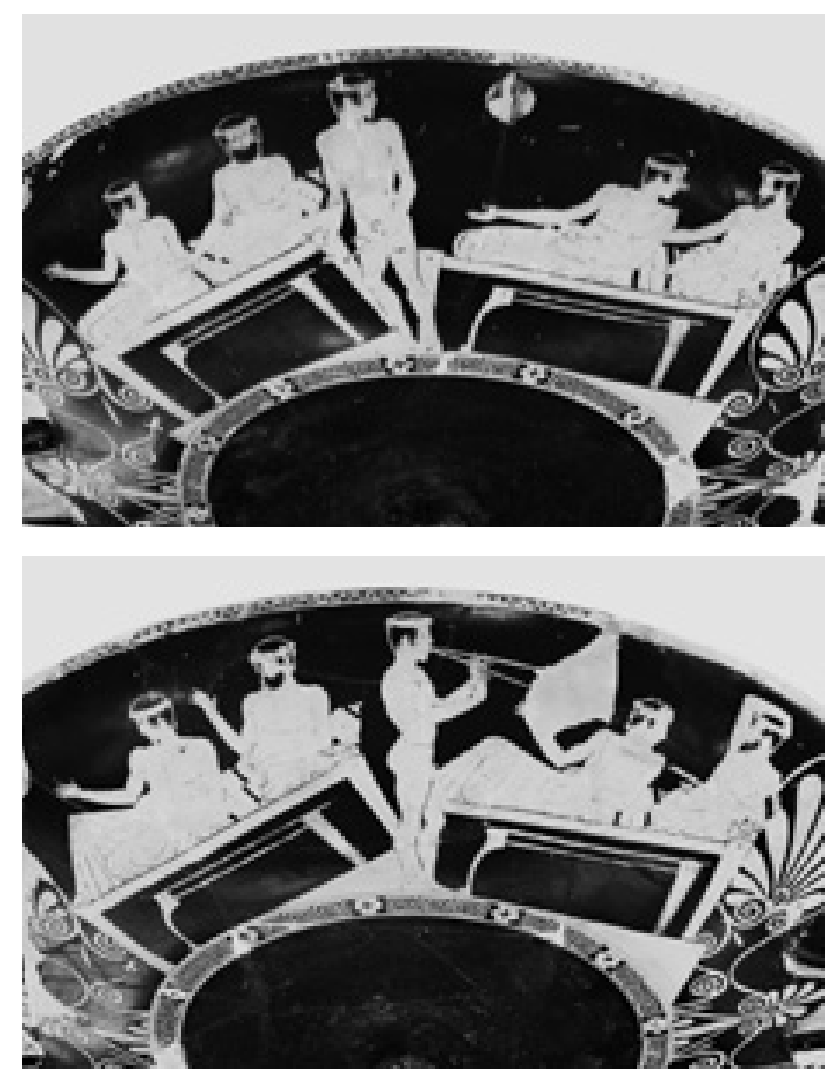

14/15 Geneva, Musée d'Art et d'Histoire I 519: Red-figure cup, Sides A-B

80 Geneva, Musee d'Art et d'Histoire I 519. ARV² 792, 49; CVA Geneva (1) 18, pl. 10 figs. 3.4 . 
ignores the companion who turns to him with a speaking gesture and instead looks out directly at the viewer, perhaps an indication that he is inebriated. ${ }^{81}$ The other couple on this side engage in a lively conversation, with the older man gently slipping his hand around the other's back. ${ }^{82}$

In the years ca. 450-425 such all-male symposium scenes are extremely popular in the vase-painters' repertoire, with perhaps close to 100 extant examples (cf. Figs. 10-11). One noticeable feature is a relatively sudden change in the repertoire of shapes. It is true that in the years of the Pioneers of red-figure (ca. 520-500), great artists such as Euphronios and Smikros painted ambitious symposia on the large canvas of a calyx-krater or stamnos (cf. Fig. 12). ${ }^{83}$ But in the Late Archaic period (ca. 500-470), the great heyday of the symposium, the motif appears most often on drinking-cups by such masters as Makron, Douris, and their contemporaries. ${ }^{84}$ The Euaion Painter, in the 460 's, continues this tradition (cf. Figs. 14-15). But starting about 450, almost all the 'Periklean symposia' appear on sizeable stamnoi or kraters, usually column-kraters (cf. Fig. 11) or bell-kraters (cf. Fig. 10). This monumentalization of the theme, in contrast to the previous generation, goes hand-in-hand with the new spirit of restrained, dignified behavior ${ }^{85}$ (along with the absence of hetairai), and a pervasive homoerotic ethos.

Many of these Periklean symposium scenes-close to fifty in all-emanated from the large workshop associated with the painter Polygnotos (not to be confused with the celebrated wall-painter from Thasos of the same name, who was active in Athens a generation earlier).$^{86}$ The absence of hetairai is absolutely consistent in

81 See Korshak 1987, 11-14, who notes that in bearded/beardless pairs of symposiasts, it is always the older man who is depicted with a frontal face. Cf. the same motif on the Euphronios krater (Fig. 12).

82 Cf. the Tomb of the Diver (below n. 87).

83 Euphronios: above n. 67; Smikros: above n. 71.

84 See, e.g., Kunisch 1997, 110-115; Buitron-Oliver 1995.

85 So also Schäfer 1997, 73. 88.

86 See Matheson 1995, for the workshop and esp. 283-287, for the symposium scenes. these scenes. The intimacy between the pederastic couple is never expressed in more than a restrained gesture, such as the older lover laying a hand on the youth's shoulder, ${ }^{87}$ yet the homoerotic ambience is palpable.

In some instances, the painter goes a bit further and seems to play subtlely on the pederastic relationship in gently humorous ways. On a stamnos in Munich (Fig. 16), ${ }^{88}$ for example, a bearded lover concentrates on the game of kottabos while his beloved is completely enraptured by the music of the aulos-player and

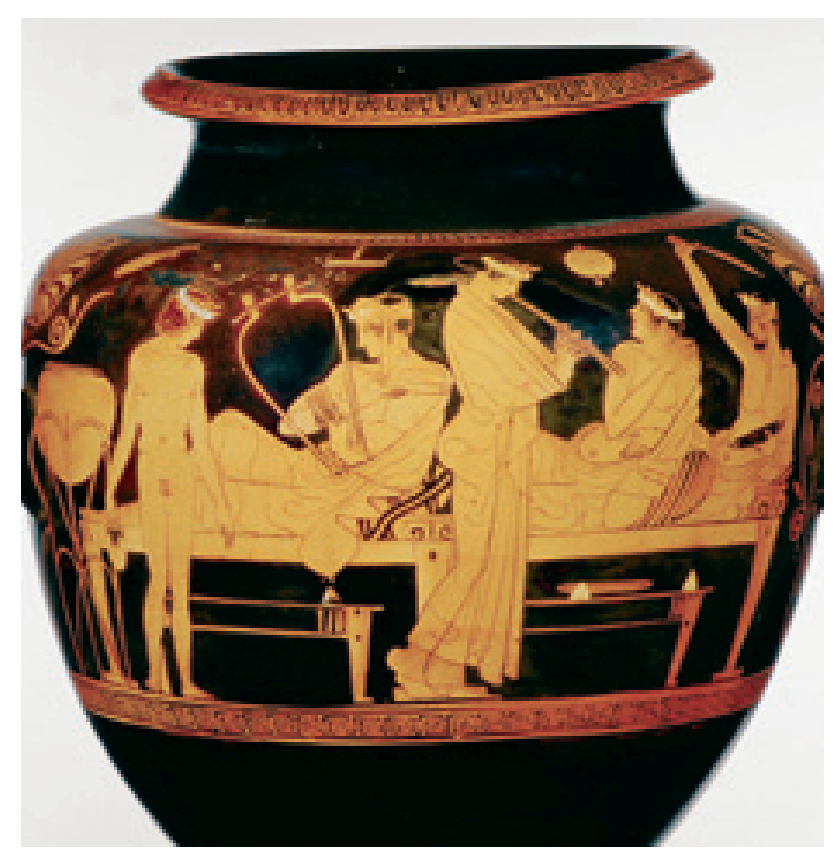

16 Munich, Staatliche Antikensammlungen 2410: Red-figure stamnos

87 The first example of this motif in a major work of art is not Athenian at all, but rather in the Tomb of the Diver at Paestum. See Napoli 1970. Here two pairs of bearded and beardless occupy adjacent klinai and one erastes slips his arm affectionately around his lover's body. The tomb is dated $480-470$.

88 Munich, Staatliche Antikensammlungen 2410. ARV 21069 , bottom 1; CVA Munich (5) pll. 250. 251; Latacz et al. 2008, 336. 
ignores him. At the same time, the youth on the other kline leers ostentatiously at the serving-boy, whose full frontal nudity is turned provocatively to the viewer. ${ }^{89}$ This could be read as a play on the ritualized age categories in pederastic relationships, and on that delicately transitional stage when the youth who has until now been the object of older lovers' attentions begins to discover the role of mature lover in the presence of a young beauty. We may be reminded of the well-known scene at the beginning of Plato's Charmides, when the older youths at the palestra, who are themselves not yet beyond adolescence, vie for the attention of the most beautiful younger boy, Charmides. Even Socrates himself "catches fire" from a glimpse inside Charmides' garment.

The gently comic potential of pederastic encounters is evident, several decades before Plato, in the unlikely context of a religious ritual, on a remarkable krater also of the Polygnotan Group in the third quarter of the fifth century (Fig. 17).$^{90}$ In the midst of a solemn procession to an altar for an animal sacrifice before the statue of Apollo, a bearded man suddenly turns to cast a lascivious glance at, and lay a hand on, a fully nude youth. ${ }^{91}$ This is not to say that the scene is a snapshot of everyday life, since it is unlikely that participants in sacrifices were ever completely undressed. But in the context of a symposium where this krater would have been used, the image evokes what must have been common knowledge, that public festivals were good occasions for men to ogle, and perhaps even pick up, attractive boys. We are specifically told that the adulterer in Lysias' speech On the Murder of Eratosthenes, spotted his illicit female lover at a funeral (Lys. 1, 20), so it should not surprise us if homosexual intrigue also took place on such public and religious occasions.

89 See Hoesch 1990.

90 Frankfurt, Archäologisches Museum b 413. ARV ${ }^{2}$ 1683; CVA Frankfurt (2) pl. 78 ; Gebauer 2002, 383-387 fig. 251. For the motif of a mature man leering at a nude youth, cf. below p. 40 .

91 Dover also recognized the gesture as sexually motivated, Dover 1978, 93 though this is questioned by Gebauer 2002, 386

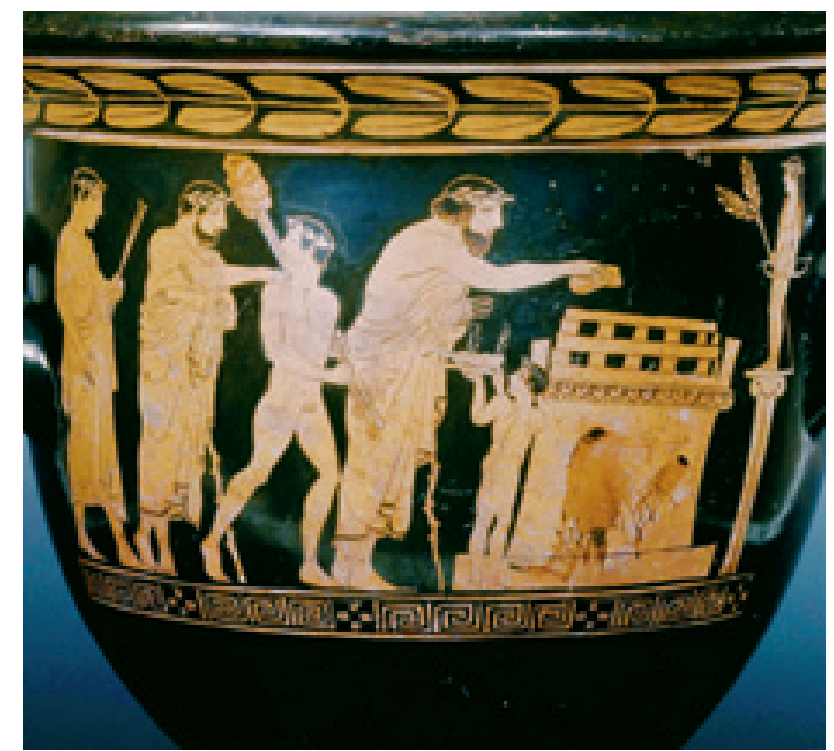

17 Frankfurt a. M., Archäologisches Museum b 413: Red-figure bell-krater

Before leaving the vases of the Polygnotan Group, we may take note of another phenomenon that could have some bearing on our investigation. A small group of contemporary scenes, most of them broadly similar to the sacrifice on the krater in Frankfurt (cf. Fig. 17), add inscribed names of men who are known to us from other sources. They include Aresias, Kallias, and Hippokles. ${ }^{92}$ In every case that can be documented, they are conservative aristocrats, leading Beazley and Webster to describe the occasions as "an oligarchs' sacrifice" or "a nest of very conservative Athenians" ${ }^{93}$ There is some reason to believe that the sacrifice is always to the

92 E.g. Boston, Museum of Fine Arts 95.25. ARV 2 1149, 9; Webster 1972, 50 pl. 3. There is a fourth name on this vase, Mantitheos, who is otherwise unknown, and the final sigma of a name that Matheson suggests could be restored as Kritias, Matheson 1995, 412. This of course would be none other than the extreme oligarch discussed above p. $25 \mathrm{f}$.

93 Webster 1972, 50; Beazley 1929, 366 f.; Matheson 1995, 276-278. 
same god, Apollo. ${ }^{94}$ In light of the strongly oligarchic flavor of these specially-commissioned symposium vases, it is tempting to see the homoerotic jokes on the Munich stamnos (cf. Fig. 16) and the Frankfurt krater (cf. Fig. 17) in the context of conservative élite circles that clung to the old-fashioned traditions of pederastic courtship.

\section{ANAKREON, THE MODEL ERASTES}

What bearing does all this have on the portrait statue of Anakreon? A careful examination of his surviving verse suggests that he was not only the poet par excellence of the symposium, but that he was known as the arbiter par excellence of the songs that were appropriate for the symposium. ${ }^{95}$ Often this meant witty poems about love, and especially about pederastic love in the sympotic context..$^{96}$ Many poems and fragments are addressed to beautiful youths who are extravagantly praised. An epigram in the Greek Anthology, ascribed to Theokritos (9, 599), concludes with words to the effect that Anakreon's pleasure in young men "is all you need to know about him". Typical of many later anecdotes and biographical comments is an observation of Maximus of Tyre (24, $9=$ fr. 471), that Anakreon was "always in love with the beautiful ... the hair of Smerdis, the eyes of Kleoboulos, and the youthful beauty of Bathyllos". Yet in the same breath, Maximus adds that Anakreon always pursued these affairs "with sophrosyne". According one of the most famous anecdotes, when the tyrant Polykrates became jealous of Anakreon's interest in the young Smerdis and, out of spite, had the boy's beautiful hair cut off, Anakreon wisely reacted not by criticizing his patron, but by wittily accusing the

94 Shapiro $1996 \mathrm{~b}$.

95 Gentili 1988, 89-94; Ford 2002, 42 f. For a sensitive appreciation of the statue as an expression of Anakreon's poetry, see Schäfer 2002, 289.

96 Rosenmeyer 1992, 17 f.; Lear 2007, with earlier references. boy of taking up arms against his own hair (Ail. var. 9, 4). ${ }^{97}$ Another epigram in the Greek Anthology $(7,24)$, this one attributed to Simonides, refers to Anakreon's “boy-loving lyre”. When asked why he did not write hymns to the gods, he famously replied, "Boys are our gods" (Sch. Pind. I. 2, 1b).98

This is not to say that Anakreon never shows an erotic interest in women (see below), but the pederastic love-poems predominate. In these, the poetic persona of Anakreon is most often that of the would-be erastes who, like the bearded men in the symposium and sacrifice scenes, longs for the youth in his company, gently importunes him, but never captures the object of his affection..$^{99}$ He sees himself as constantly at war with Eros, who inflames him with desire for one youth or another, but never allows him to find reciprocation. ${ }^{100}$ Like the infibulated penis of the Copenhagen statue, he is tied up in knots from unrequited desire.

Yet his erotic poetry is also marked by a kind of sophrosyne, in that he rarely uses explicitly sexual language, as some of his predecessors, such as the iambic poets Archilochos and Hipponax, do. The closest he comes (still without any actual obscenity) is in a short fragment that has interesting parallels in the world of vase-painting:

\section{à $\lambda \lambda \grave{\alpha} \pi \rho o ́ \pi ı v \varepsilon$ \\ }

Come, pledge me, dear boy, your slender thighs. ${ }^{101}$

97 Cf. the recent comment of Bowie on Anakreon's "self-representation as a desiring, drinking, jesting, autonomous and parrhesiastic member of a sympotic group", Bowie 2009. But contrast Kantzios 2010, who emphasizes the "marginal persona" adopted by Anakreon as an itinerant outsider at the courts where he entertained and the relevance of this stance for his erotic poetry.

98 Cited most recently by Lear-Cantarella 2008, p. V. There is in fact a hymn to Artemis in the corpus of Anakreon, what Bowra "calls a personal prayer", Bowra 1961, 273.

99 Rosenmeyer 1992, 40-45.

100 Williamson 1998.

101 Sch. Pind. O. fr. 407. 
The line is cited by the Scholiast because of the substitution of the word propine, usually used of pledging a cup of wine, for the more usual charizou ("grant me"). In other words, there is a sly bit of humor in the poet's starting out as if making a toast and, in the final word, unexpectedly asking for a sexual favor. The singling out of the thighs as an erogenous zone has an earlier Athenian precedent in a fragment of Solon, who praises a boy's handsome thighs (fr. 25 West). ${ }^{102}$ Given the painters' insistence on a form of intercourse that involves the boy's thighs (Beazley's “intercrural"), we may wonder if the mere mention of the word meroi did not carry a sexual connotation. This in indeed confirmed by the unique inscription on a now-lost black-figure lekythos of the late sixth century, the period of Anakreon's residence in Athens. ${ }^{103}$ In a scene set in the palestra, a bearded man turns to leer at one of the boys exercising in the nude. The letters spilling from his mouth crudely convey his thoughts: "AПO $\triangle \mathrm{O} \Sigma$ TO $\triangle \mathrm{IAMEPION"-}$

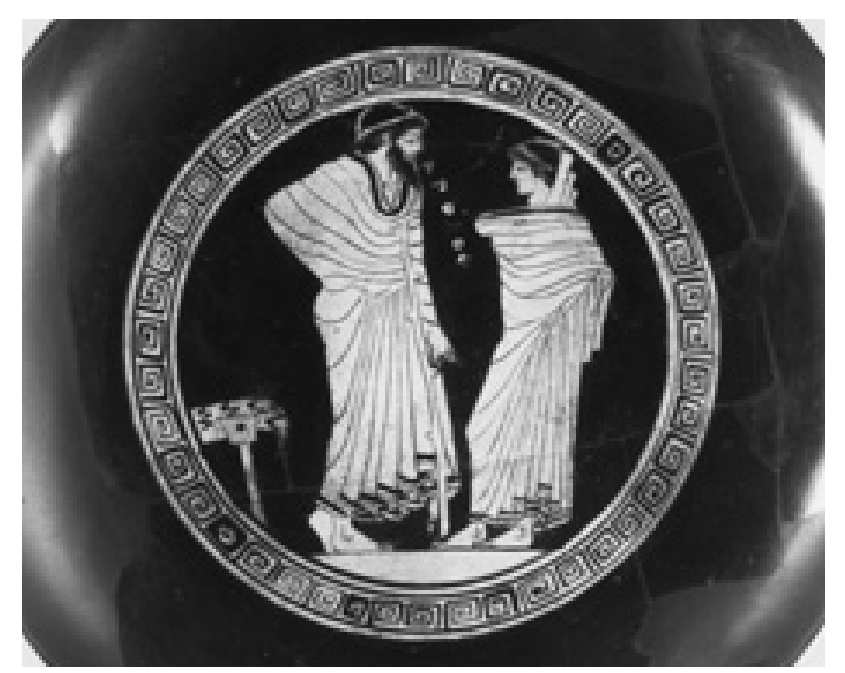

18 Richmond, Virginia Museum of Fine Arts 56-27-5: Red-figure cup

102 See Dover 1978, 70

103 Kephalidou 1996, pl. 28.
"Give me [access to] that place between your thighs". This inscription in turn explains the previously enigmatic letters on a somewhat later red-figure cup tondo, with a man opposite a youth (Fig. 18). ${ }^{104}$ The single word $\mathrm{A} \Pi \mathrm{O} \Delta \mathrm{O} \Sigma$, in large letters, is clearly abbreviated from the full phrase that we have attested on the earlier vase. The rather brusque and unsubtle use of the imperative apodos contrasts with Anakreon's elegantly witty rephrasing of the same idea. ${ }^{105}$

Sexual orientation is invariably politicized in all historical periods. In the later fifth century, the form of pederasty practised by élite Athenian men was increasingly viewed with disdain by the democratic majority, as can be seen in the plays of Aristophanes and elsewhere. ${ }^{106}$ Yet the defenders of pederasty had hardly retreated into the closet. They could point to the Tyrannicides, Harmodios and Aristogeiton, whose eroticized nude figures stood conspicuously in the Agora, as models of a noble pederasty that had freed Athens from tyranny. ${ }^{107}$ Even Aristophanes' characters are not crudely dismissive of pederasty; rather, it is explicitly associated with the generation of the heroes of Marathon: quaintly old-fashioned by now, but certainly not effeminate or decadent. So, for example, in the debate between Dikaios and Adikos Logos at Clouds 961-1023, the former cites the generation of the Marathonomachoi, when the youth were rigorously trained and displayed their naked bodies for the delectation of mature men but were at the same time modest and unassuming. These are contrasted with the effeminate young men of present-day Athens.

104 Richmond, Virginia Museum of Fine Arts 56-27-5. Brown 1973, 90 no. 106.

105 For such imperative verbs in a homoerotic context cf. the well-known red-figure fragments with a bit of dialogue between a bearded man and his unwilling lover: "Hold still ... won’t you stop?". See Stähli 2001, 202 fig. 2.

106 Hubbard 1988

107 See Monoson 2000; Stewart 1997, 73, who speaks of the statue group as representing a "homoerotic political ideology". Daehner comments that Aristogeiton's garment sets off his nudity and emphasizes his role as erastes in trying to protect Harmodios, Daehner 2005, $291 \mathrm{f}$. 
Anakreon himself wrote invective poems satirizing effeminate men, by which he meant not those of homosexual orientation, but, if anything, its opposite, an excess of heterosexuality. The most famous of these targets, Artemon, frequented common whores when he was still poor, but now that he is rich and is carried about on a litter, he has a fancy lover named Eurypyle. ${ }^{108}$ The model for this kind of effeminate heterosexuality would seem to be Paris in the Iliad, the luxurious barbarian prince whose adulterous passion for Helen cripples his manliness. Another of Anakreon's targets is apparently a man who plays the passive role in sexual relations with his wife: "He did not marry her, but he was married."

\section{CONCLUSIONS}

The portrait statue of Anakreon, I suggest, with its confident masculinity and proudly displayed nude body, reflects the ideal of a muscular, manly pederasty that was already viewed as oldfashioned by the middle of the fifth century. If Anakreon was remembered as the prototype of the noble erastes, who celebrated the joys and agonies of homoerotic desire, it would have been in conservative and aristocratic circles that he was most admired, and it was with them that the statue on the Akropolis must have originated.

One discordant note in this scenario is the epigram by the younger Kritias alluded to earlier. ${ }^{109}$ For, far from referring to Anakreon's pederastic interests, it paints a very different picture of the poet as one who "broke ladies' hearts". ${ }^{110}$ But this image is

108 For discussion of this poem, see Brown 1983. Artemon's earrings and parasol are 'effeminate' in the sense of decadent luxuries, but have no sexual connotations (and are certainly not transvestite) in and of themselves. Cf. the 'Anacronies' discussed above p. 19.

109 Above p. 25.

110 Kritias fr. 500 PMG line 34. Translation after Rosenmeyer 1992, 16. In other translations he is called a "deceiver of women", Campbell 1988, 139 . so much at odds with both the anecdotes we have about Anakreon and the surviving poetry itself that it strains credulity. It is not that Anakreon has no interest in or desire for women. But when he does, his poetic persona is not that of a lady-killer, but quite the opposite, the scorned older lover, usually because of his advancing age. Best known is the poem about a "Thracian filly", evidently a wild Thracian girl who rejects him as too staid and unable to keep up (fr. 417 PMG). Kritias also specifically refers twice to Anakreon's poetry being performed by choruses of women (as if he were Alkman), a genre for which there is no evidence whatever among the surviving fragments. ${ }^{111}$ It would seem that Kritias had his reasons to promulgate a radically different image of Anakreon, perhaps even to counter a popular perception of the poet as an archetypal pederast.

In the end, I think we may conclude that the statue of Anakreon on the Akropolis - its pose and physiognomy, and especially its nudity - could have been read in a number of different ways by the Athenians who went to admire it. The old concept of 'heroic nudity' has been often problematized in recently scholarship, ${ }^{112}$ but it is nevertheless true that by the 440's, Anakreon will have enjoyed a quasi-legendary status, ${ }^{113}$ and it was not uncommon for poets to receive posthumous cult worship in other parts of the Greek world. ${ }^{114}$ This is surely one aspect of the statue's nudity. Another is the association with the world of symposium and komos, where, at least in art (to judge by the vases), if not in life, mature men could still be shown nude. ${ }^{115}$ But I would suggest that a third connotation is the one that has been staring us in the face all along, namely, that, for the Greek viewer of either sex, the nude male body is an eroticized body ${ }^{116}$ And for Anakreon, that means that, as much as Aristogeiton in the Agora, he would have been

111 Rosenmeyer 1992, 38

112 Bonfante 1989; Himmelmann 1990; Hölscher 1993; Daehner 2005; Hurwit 2007.

113 Himmelmann 1990, 77.

114 Clay 2004.

115 Voutiras 1980, 91

116 Stewart 1997, 67 and passim. 
recognized in some circles as a model of the noble erastes. Both men belonged to roughly the same generation, though there the biographical similarities end. ${ }^{117}$ Anakreon was neither an aristocrat nor even an Athenian. But then neither was Aristogeiton a freedom-fighter who set out to topple the tyrants and establish Athens as a democracy. Yet such is the power of popular belief that he soon became precisely that in Athenian memory. ${ }^{118}$ So, too, Anakreon, a mere forty years after his death, became the great exponent of a uniquely Athenian form of idealized pederasty in an era when sexual politics were as hotly contested as they are today.

\section{REFERENCES}

Aloni 2000 A. Aloni, Anacreonte a Atene. Datazione e significato di alcune iscrizioni tiranniche, ZPE 130, 2000, 81-94

Avramidou 2006 A. Avramidou, Attic Vases in Etruria. Another View on the Divine Banquet Cup by the Codrus Painter, AJA 110, 2006, 565-579 Beazley 1929 J. D. Beazley, Some Inscriptions on Vases II, AJA 33, 1929, 361-367

Beazley 1989 J. D. Beazley, Some Attic Vases in the Cyprus Museum. Ed. D. C. Kurtz (Oxford 1989)

Becatti 1951 G. Becatti, Problemi Fidiaci (Milan 1951)

Bonfante 1989 L. Bonfante, Nudity as Costume in Classical Art, AJA 93, 1989, 543-570

Bowie 2009 E. Bowie, Wandering Poets, Archaic Style, in: I. Rutherford (ed.), Wandering Poets in Ancient Greek Culture (Cambridge 2009) 105-136

Bowra 1961 C. M. Bowra, Greek Lyric Poetry from Alcman to Simonides (London 1961)

Bremmer 1990 J. Bremmer, Adolescents, Symposion, and Pederasty, in: O. Murray (ed.), Sympotica. A Symposium on the Symposion (Oxford 1990) 135-148

Brown $1983 \mathrm{Ch}$. Brown, From Rags to Riches. Anacreon's Artemon, Phoenix 37, 1983, 1-15

Brown 1973 J. Brown, Ancient Art in the Virginia Museum (Richmond 1973)

Brusini 1996 S. Brusini, L’Anacreonte Borghese. Una nuova proposta di lettura, RdA 20, 1996, 59-74

Buitron-0liver 1995 D. Buitron-Oliver, Douris. A Master-Painter of Athenian Red-Figure Vases (Mainz 1995)

Bundrick 2005 S. D. Bundrick, Music and Image in Classical Athens (Cambridge 2005)

Burkert 1987 W. Burkert, The Making of Homer in the Sixth Century B. C. Rhapsodes Versus Stesichoros, in: Papers on the Amasis Painter and his World (Malibu 1987) 43-62

Campbell 1988 D. Campbell, Greek Lyric II. Anacreon, Anacreontea, Choral Lyric from Olympis to Alcman (Cambridge 1988)

Caskey-Beazley 1954 L. D. Caskey-J. D. Beazley, Attic Vase Paintings in the Museum of Fine Arts Boston II (Boston 1954)

Clay 2004 D. Clay, Archilochos Heros. The Cult of Poets in the Greek Polis (Washington 2004)

Daehner 2005 J. Daehner, Die Grenzen der Nacktheit, JdI 120, 2005, 155-299

Davies 1971 J. K. Davies, Athenian Propertied Families (Oxford 1971)
117 On the family of Aristogeiton, see Davies 1971, $473 \mathrm{f}$ 118 Taylor 1991. 
Delavaud-Roux 1995 M.-H. Delavaud-Roux, L'énigme des danseurs barbus au parasol et les vases des Lénéennes, RA 1995, 227-263 DeVries 1972/73 K. DeVries, East Meets West at Dinner, Expedition $15 / 4,1972 / 73,32-39$

Dover 1978 K. J. Dover, Greek Homosexuality (London 1978)

Ford 2002 A. Ford, The Origins of Criticism. Literary Culture and Poetic Theory in Classical Greece (Princeton 2002)

Frel 1963 J. Frel, Griechischer Eros, LF 86, 1963, 60-64

Frontisi-Ducroux-Lissarrague 1983 F. Frontisi-Ducroux-F. Lissarrague,

De l'ambiguïté à l'ambivalence. Un parcour dionisiaque, AIONArch 5, 1983, 11-32; re-published in English as: F. Frontisi-DucrouxF. Lissarrague, From Ambiguity to Ambivalence. A Dionysiac Excursion through the 'Anakreontic' Vases, in: D. M. Halperin et al. (eds.), Before Sexuality (Princeton 1990) 211-256

Furtwängler 1893 A. Furtwängler, Meisterwerke der griechischen Plastik (Leipzig 1893)

Gauer 1968 W. Gauer, Die griechischen Bildnisse der klassischen Zeit als politische und persönliche Denkmäler, JdI 83, 1968, 118-179

Gebauer 2002 J. Gebauer, Pompe und Thysia (Münster 2002)

Gentili 1988 B. Gentili, Poetry and its Public in Ancient Greece, trans A. Th. Cole (Baltimore 1988)

Godart-De Caro 2007 L. Godart-S. De Caro (eds.), Nostoi. Capolavori ritrovati. Exhibition catalogue Rome (Rome 2007)

Hafner 1956 G. Hafner, Anakreon und Xanthippos, JdI 71, 1956, 1-28

Heinrich 2007 F. Heinrich, Bodengelage im Reich des Dionysos, in: M. Meyer (ed.), Besorgte Mütter und sorglose Zecher. Mythische Exempel in der Bilderwelt Athens (Vienna 2007) 101-156

Herington $1985 \mathrm{~J}$. Herington, Poetry into Drama. Early Tragedy and the Greek Poetic Tradition (Berkeley 1985)

Himmelmann 1990 N. Himmelmann, Ideale Nacktheit in der griechischen Kunst, JdI Ergh. 26 (Berlin 1990)

Himmelmann 1995 N. Himmelmann, Review of Paul Zanker, Die Maske des Sokrates, BJb 195, 1995, 653-661

Himmelmann 2001 N. Himmelmann, Die private Bildnisweihung bei den Griechen, AbhDüsseldorf G 373 (Opladen 2001)

Hoesch 1990 N. Hoesch, in: K. Vierneisel-B. Kaeser (eds.), Kunst der Schale, Kultur des Trinkens. Exhibition catalogue Munich (Munich 1990) 235-237 Hölscher 1975 T. Hölscher, Die Aufstellung des Perikles-Bildnisses und ihre Bedeutung, WürzbJb (N.S.) 1, 1975, 187-218; reprinted in K. Fittschen (ed.), Griechische Porträts (Darmstadt 1988) 377-391 Hölscher 1993 T. Hölscher, Review of Himmelmann 1990, Gnomon 65, 1993, 519-528

Hubbard 1998 Th. Hubbard, Popular Perceptions of Élite Homosexuality in Classical Athens, Arion 6/1, 1998, 48-78

Hubbard 2003 Th. Hubbard (ed.), Homosexuality in Greece and Rome. A Sourcebook of Basic Documents (Berkeley 2003)
Hurwit 1999 J. M. Hurwit, The Athenian Acropolis. History, Mythology, and Archaeology from the Neolithic Era to the Present (Cambridge 1999) Hurwit 2007 J. M. Hurwit, The Problem with Dexileos. Heroic and Other Nudities in Greek Art, AJA 111, 2007, 35-60

Immerwahr 1965 H. R. Immerwahr, Inscriptions on the Anacreon Krater in Copenhagen, AJA 69, 1965, 152-154

Jones 1918 W. H. S. Jones, Pausanias. Description of Greece. Loeb Classical Library (Cambridge 1918)

Kantzios 2010 I. Kantzios, Marginal Voice and Erotic Discourse in Anacreon, Mnemosyne 63, 2010, 577-589

Keesling 2003 C. Keesling, The Votive Statues on the Athenian Akropolis (Cambridge 2003)

Kephalidou 1996 E. Kephalidou, Niketes (Thessaloniki 1996)

Kilmer 1993 M. F. Kilmer, Greek Erotica on Red-figure Pottery (London 1993)

Kilmer 1997 M. F. Kilmer, Painters and Pederasts. Ancient Art, Sexuality, and Social History, in: M. Golden-P. Toohey (eds.), Inventing Ancient Culture (London 1997) 36-49

Klug 1995 D. Klug, in: K. Stemmer (ed.), Standorte. Kontext und Funktion antiker Skulptur. Exhibition catalogue Berlin (Berlin 1995) $184 \mathrm{f}$. Korshak 1987 Y. Korshak, Frontal Faces in Attic Vase Painting of the Archaic Period (Chicago 1987)

Kotsidu 1991 H. Kotsidu, Die musischen Agone der Panathenäen in archaischer und klassischer Zeit (Munich 1991)

Krumeich 1997 R. Krumeich, Bildnisse griechischer Herrscher und Staatsmänner im 5. Jahrhundert v. Chr. (Munich 1997)

Kunisch 1997 N. Kunisch, Makron, Forschungen zur Antiken Keramik II, Kerameus 10 (Mainz 1997)

Kurtz-Boardman 1986 D. C. Kurtz-J. Boardman, 'Booners', Greek Vases in the J. Paul Getty Museum 3 (Malibu 1986) 35-70

Latacz et al. $2008 \mathrm{~J}$. Latacz-T. Greub-P. Blome-A. Wieczorek (eds.), Homer. Der Mythos von Troia in Dichtung und Kunst. Exhibition catalogue Basel (Munich 2008)

Lear 2007 A. Lear, Anacreon's 'Self'. An Alternate Role Model for the Archaic Élite Male?, AJPh 129, 2007, 47-76

Lear-Cantarella 2008 A. Lear-E. Cantarella, Images of Greek Pederasty (London 2008)

Lissarrague 1990 F. Lissarrague, The Aesthetics of the Greek Banquet, trans. A. Szegedy-Maszak (Princeton 1990)

Matheson 1995 S. B. Matheson, Polygnotos and Vase-Painting in Classical Athens (Madison 1995)

Metzler 1971 D. Metzler, Porträt und Gesellschaft (Münster 1971)

Meyer 1993 M. Meyer, Der kleine Unterschied. Ideelle und materielle Aspekte der 'Liebeswerbung' in der Antike (Stendal 1993)

Miller 1999 M. Miller, Reexamining Transvestism in Archaic and Classical Athens. The Zewadski Stamnos, AJA 103, 1999, 223-253 
Moltensen 1987 M. Moltesen, From the Princely Collections of the Borghese Family to the Glyptotek of Carl Jacobsen, AnalRom 16, 1987, 187-203

Monoson 2000 S. S. Monoson, The Allure of Harmodios and Aristogeiton, in: Th. Hubbard (ed.), Greek Love Reconsidered (New York 2000) 42-51 Napoli 1970 M. Napoli, La Tomba del Tuffatore (Bari 1970)

Neer 2002 R. T. Neer, Style and Politics in Athenian Vase-Painting (Cambridge 2002)

Padgett 2002 J. M. Padgett, A Unique Vase in the Metropolitan Museum of Art, in: A. J. Clark-J. Gaunt (eds.), Essays in Honor of Dietrich von Bothmer (Amsterdam 2002) 249-266

Papaspyridi-Karouzou 1942/43 S. Papaspyridi-Karouzou, Anacréon à Athènes, BCH 66/67, 1942/43, 248-254

Peschel 1987 I. Peschel, Die Hetäre bei Symposion und Komos (Frankfurt 1987)

Poulsen 1931 F. Poulsen, Iconographical Studies in the Ny Carlsberg Glyptothek, From the Collections of the Ny Carlsberg Glyptotek 1 (Copenhagen 1931)

Price 1990 S. Price, Anacreontic Vases Reconsidered, GrRomByzSt 31, 1990, 133-175

Richter 1965 G. M. A. Richter, The Portraits of the Greeks I (London 1965) Ridgway 1998 B. Sismondo Ridgway, An Issue of Methodology. Anakreon, Perikles, Xanthippos, AJA 102, 1998, 717-738

Rosenmeyer 1992 P. Rosenmeyer, The Poetics of Imitation. Anacreon and the Anacreontic Tradition (Cambridge 1992)

Schauenburg $1965 \mathrm{~K}$. Schauenburg, Erastes und Eromenos auf einer Schale des Sokles, AA 80, 1965, 849-867

Schäfer 1997 A. Schäfer, Unterhaltung beim griechischen Symposion (Mainz 1997)

Schäfer 2002 A. Schäfer, Alte Werte, neue Bilder. Das Trinkgelage klassischer Zeit in Athen, in: Die griechische Klassik. Idee oder Wirklichkeit. Exhibition catalogue Berlin (Berlin 2002)

Schefold 1997 K. Schefold, Die Bildnisse der antiken Dichter, Denker und Redner (Basel 1997)

Shapiro 1981 H. A. Shapiro, Art, Myth, and Culture. Greek Vases from Southern Collections. Exhibition catalogue New Orleans (New Orleans 1981)

Shapiro 1992 H. A. Shapiro, Music and Poetry at the Panathenaia, in: J. Neils (ed.), Goddess and Polis. The Panathenaic Festival in Ancient Athens. Exhibition catalogue Hanover (N. H.) 1992, 53-75

Shapiro 1993 H. A. Shapiro, Hipparchos and the Rhapsodes, in: C. Dougherty-L. Kurke (eds.), Cultural Poetics in Archaic Greece (Cambridge 1993) 92-107

Shapiro 1996a H. A. Shapiro, Democracy and Empire. The Panathenaia in the Age of Perikles. In: J. Neils (ed.), Worshiping Athena (Madison 1996) 215-225
Shapiro 1996b H. A. Shapiro, Athena, Apollo, and the Religious Propaganda of the Athenian Empire, in: P. Hellström-B. Alroth (eds.), Religion and Power in the Ancient Greek World (Uppsala 1996), 101-115

Smith 2007 R. R. R. Smith, Pindar, Athletes, and the Statue Habit, in: S. Hornblower-C. Morgan (eds.), Pindar's Poetry, Patrons, and Festivals (Oxford 2007) 83-139

Stähli 2001 A. Stähli, Der Körper, das Begehren, die Bilder. Visuelle Strategien der Konstruktion einer homosexuellen Männlichkeit, in: R. von den Hoff-S. Schmidt (eds.), Konstruktionen von Wirklichkeit (Stuttgart 2001) 197-209

Stewart 1997 A. Stewart, Art, Desire and the Body (Cambridge 1997)

Sutton 1992 R. F. Sutton Jr., Pornography and Persuasion on Attic Pottery, in: A. Richlin (ed.), Pornography and Representation in Greece and Rome (Oxford 1992), 3-35

Sweet 1987 W. E. Sweet, Sport and Recreation in Ancient Greece (Oxford 1987) 129-132

Taylor 1991 M. W. Taylor, The Tyrant Slayers² (Salem 1991)

Tiverios 1989 M. A. Tiverios, Perikleia Panathenaia (Athens 1989)

Topper $2009 \mathrm{~K}$. Topper, Primitive Life and the Construction of the Sympotic Past in Athenian Vase-Painting, AJA 113, 2009, 3-26

Vermeule 1965 E. Vermeule, Fragments of a Symposium by Euphronios, AntK 8, 1965, 34-39

Vierneisel $1991 \mathrm{~K}$. Vierneisel, in: Euphronios der Maler. Exhibition catalogue Berlin (Milan 1991) 89

v. Bothmer 1972-1973 D. v. Bothmer, Greek Vase Painting. An Introduction, BMetrMus 31, 1972-1973, 1-68

von den Hoff 2009 R. von den Hoff, Die Bildnisstatue des Demosthenes als öffentliche Ehrung eines Bürgers in Athen, in: Chr. MannM. Haake-R. von den Hoff (eds.): Rollenbilder in der athenischen Demokratie (Wiesbaden 2009) 193-220

Voutiras 1980 E. Voutiras, Studien zu Interpretation und Stil griechischer Porträts des 5. und frühen 4. Jahrhunderts (Bonn 1980)

Webster 1972 Th. B. L. Webster, Potter and Patron in Classical Athens (London 1972)

Williamson 1998 M. Williamson, Eros the Blacksmith. Performing Masculinity in Anacreon's Love Lyrics, in: L. Foxhall-J. Salmon (eds.), Thinking Men (London 1998) 71-81

Yatromanolakis 2009 D. Yatromanolakis, Symposia, Noses, Prosopa. A Kylix in the Company of Banqueters on the Ground, in: D. Yatromanolakis (ed.), An Archaeology of Representations. Ancient Greek Vase-Painting and Contemporary Methodologies (Athens 2009) 414-464

Zanker 1995 P. Zanker, Die Maske des Sokrates (Munich 1995)

Zimmermann 2011 B. Zimmermann, Handbuch der griechischen Literatur der Antike I (München 2011) 213-217 


\section{PHOTO CREDITS}

1-5 Copenhagen, Ny Carlsberg Glyptotek

6 B. Malter (Mal75.1)

7. 9. 10.13 London, British Museum

8 Copenhagen, National Museum

11 Baltimore, Walters Art Museum

12.16 Munich, Staatliche Antikensammlungen

14. 15 Geneva, Musée d'Art et d'Histoire

17 Frankfurt a. M, Archäologisches Museum Frankfurt a. M

18 Richmond, Virginia Museum of Fine Arts (CVirginia Museum

of Fine Arts, Richmond. Adolph D. and Wilkins C. Williams Fund)

\section{TEXT CREDIT}

Quotation from James Longenbach's poem "Exercise" (2009) by permission of the author 


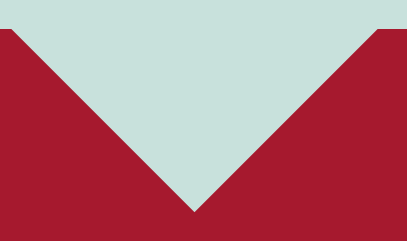

Alan Shapiro (born 1949) is the W. H. Collins Vickers Professor of Archaeology, Department of Classics, at Johns Hopkins University (Baltimore). In 20092010, he was a Fellow at the Internationales Kolleg Morphomata, University of Cologne. He is the author of Art and Cult under the Tyrants in Athens (1989); Myth into Art (1994), and, with Nikos Kaltsas, Worshipping Women: Ritual and Reality in Classical Athens (2008). He is a Fellow of the Alexander von Humboldt-Stiftung and a Corresponding Member of the German Archaeological Institute.
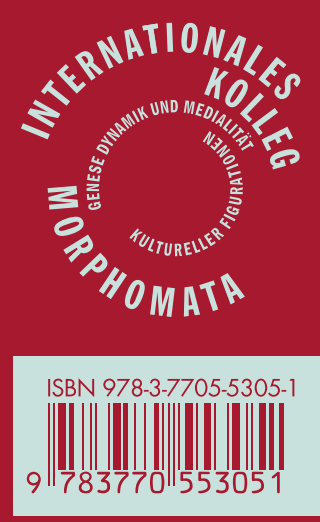

WILHELM FINK 